University of South Florida

DIGITAL COMMONS

@ UNIVERSITY OF SOUTH FLORIDA
Digital Commons @ University of

South Florida

$4-1-2004$

\title{
Evaluation of Shared Use Park and Ride Impact on Properties
}

CUTR

Follow this and additional works at: https://digitalcommons.usf.edu/cutr_nctr

\section{Scholar Commons Citation}

CUTR, "Evaluation of Shared Use Park and Ride Impact on Properties" (2004). Research Reports. 233.

https://digitalcommons.usf.edu/cutr_nctr/233

This Technical Report is brought to you for free and open access by the National Center for Transit Research (NCTR) Archive (2000-2020) at Digital Commons @ University of South Florida. It has been accepted for inclusion in Research Reports by an authorized administrator of Digital Commons @ University of South Florida. For more information, please contact digitalcommons@usf.edu. 


\section{PUBLIC TRANSPORTATION RESEARCH STUDY}

\section{Evaluation of Shared Use Park \& Ride Impact on Properties}

Francis Wambalaba, PhD, AICP

Principal Investigator

Julie Goodwill

Graduate Research Assistant

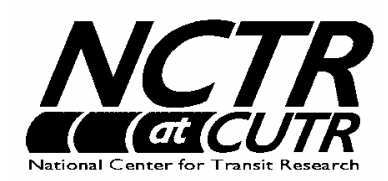

April, 2004 


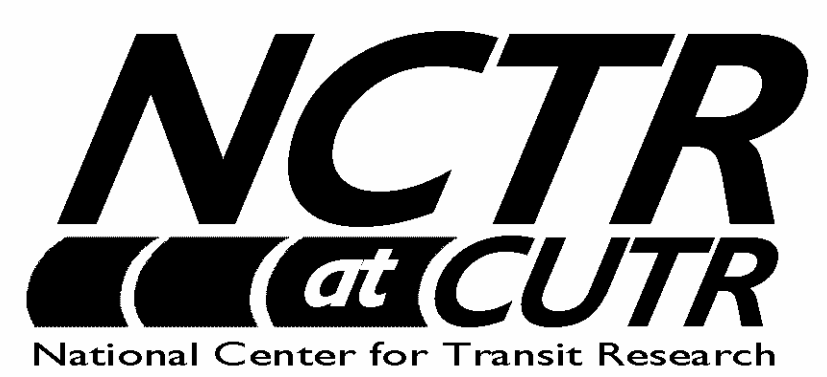

NATIONAL CENTER FOR TRANSIT RESEARCH

at the

\section{CENTER FOR URBAN TRANSPORTATION RESEARCH}

University of South Florida

4202 E. Fowler Avenue, CUT100

Tampa, FL 33620-5375

(813) 974-3120, SunCom 574-3120, Fax (813) 974-5168

Edward Mierzejewski, P.E., CUTR Director

Joel Volinski, NCTR Director

Dennis Hinebaugh, Transit Program Director

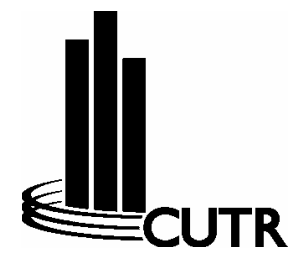

The contents of this report reflect the views of the author, who is responsible for the facts and the accuracy of the information presented herein. This document is disseminated under the sponsorship of the

Department of Transportation, University Research Institute Program, in the interest of information exchange. The U.S. Government assumes no liability for the contents or use thereof. 
TECHNICAL REPORT STANDARD TITLE PAGE

\begin{tabular}{|c|c|c|c|}
\hline $\begin{array}{ll}\text { 1. Report No. } & \text { FDOT-BC 137, RPWO \#49 } \\
& \text { NCTR-527-10 }\end{array}$ & 2. Government Acce & \multicolumn{2}{|l|}{ 3. Recipient's $\mathrm{C}_{2}$} \\
\hline \multirow{2}{*}{\multicolumn{2}{|c|}{$\begin{array}{l}\text { 4. Titte and Subitile } \\
\text { Evaluation of Shared Use Park \& Ride Impact on } \\
\text { Properties }\end{array}$}} & \multicolumn{2}{|c|}{$\begin{array}{l}\text { 5. Report Date } \\
\text { April } 2004\end{array}$} \\
\hline & & \multicolumn{2}{|c|}{ 6. Performing Organization Code } \\
\hline \multicolumn{2}{|c|}{$\begin{array}{l}\text { 7. Author(s) } \\
\text { Francis Wambalaba, PhD., AICP, and Julie Goodwill. }\end{array}$} & \multicolumn{2}{|c|}{ 8. Performing Organization Report No. } \\
\hline \multirow{2}{*}{\multicolumn{2}{|c|}{$\begin{array}{l}\text { 9. Performing Organization Name and Address } \\
\text { National Center for Transportation Research } \\
\text { Center for Urban Transportation Research } \\
\text { University of South Florida } \\
4202 \text { E. Fowler Avenue, CUT 100, Tampa FL 33620- }\end{array}$}} & \multicolumn{2}{|l|}{ 10. Work Unit No. } \\
\hline & & \multicolumn{2}{|c|}{$\begin{array}{l}\text { 11. Contract or Grant No. } \\
\text { DTRS } 98-9-0032\end{array}$} \\
\hline \multirow{2}{*}{\multicolumn{2}{|c|}{$\begin{array}{l}\text { 12. Sponsoring Agency Name and Address } \\
\text { Office of Research and Special Programs } \\
\text { U.S. Department of Transportation, Washington, D.C. } \\
\text { 20690 } \\
\text { Florida Department of Transportation } \\
605 \text { Suwannee Street, MS 26, Tallahassee, FL } 32399\end{array}$}} & \multicolumn{2}{|c|}{ 13. Type of Report and Period Covered } \\
\hline & & \multicolumn{2}{|l|}{ 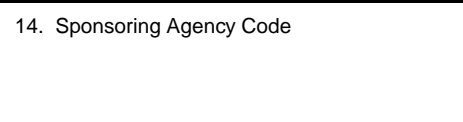 } \\
\hline \multicolumn{4}{|c|}{$\begin{array}{l}\text { 15. Supplementary Notes } \\
\text { Supported by a grant from the Florida Department of Transportation and the U.S. } \\
\text { Department of Transportation }\end{array}$} \\
\hline \multicolumn{4}{|c|}{$\begin{array}{l}\text { 16. Abstract } \\
\text { The purpose of this study is to document the economic benefit of shared use park and ride } \\
\text { facilities located at retail centers. Transit agencies usually perceive shared use park and } \\
\text { ride as mutually beneficial to both the transit agency through savings in land and } \\
\text { development costs and to park and ride providers through an increase in customer base } \\
\text { and sales. In contrast, park and ride providers may hold negative perceptions about shared } \\
\text { use park and ride and often feel that allowing a shared use park and ride on their property } \\
\text { will bring problems such as increased liability, vandalism, and litter, and will occupy } \\
\text { spaces that potential shoppers might have used. This study attempts to document whether } \\
\text { the presence of a "Shared Use Park \& Ride" has influence on shopping behavior patterns, } \\
\text { whether it generates revenues for park and ride providers, and whether it generates } \\
\text { ridership for transit service providers. }\end{array}$} \\
\hline $\begin{array}{l}\text { 17. Key Words } \\
\text { Shared use park and ride, park } \\
\text { and ride }\end{array}$ & \multicolumn{3}{|c|}{$\begin{array}{l}\text { 18. Distribution Statement } \\
\text { Available to the public through the National } \\
\text { Technical Information Service (NTIS), 5285 } \\
\text { Port Royal, Springfield, VA } 22181 \text { ph (703) } \\
\text { 487-4650 }\end{array}$} \\
\hline Unclassitied & & f pages & \\
\hline
\end{tabular}

Form DOT F 1700.7 (8-69) 


\section{Acknowledgments}

This report is prepared by the National Center for Transit Research through the sponsorship of the Florida Department of Transportation and the U.S. Department of Transportation.

\section{FDOT Project Team:}

Jon Ausman, Transit Planning Program Manager, Florida Department of Transportation

\section{CUTR Project Team:}

Principal Investigator:

Francis Wambalaba, PhD, AICP

Research Assistant:

Julie Goodwill

Principal Authors:

Francis Wambalaba, PhD., AICP, CUTR

Julie Goodwill, CUTR

Contributors:

Kimberlee Gabourel, Center for Urban Transportation Research

Reviewers:

Internal:

Rob Gregg, Center for Urban Transportation Research

Joel Volinski, Center for Urban Transportation Research

Kristine Williams, Center for Urban Transportation Research

External:

Barbara Kyung Son, PhD., CAL State University

Peter Valk, Transportation Management Services

Appreciation is expressed to the following individuals for their helpful comments:

Tom Locke, University Mall

Keith Gregory, Veterans Administration

Sheron Abernathy, Hillsborough Area Regional Transit

Susan Hancock, Manatee County Area Transit

Al Tisnes, South Florida Vanpool

Jeff Horton, Florida State University

Tom Dornfeld, Oaks Mall

Gary Bales, Kmart Stores

Sonny Mesnith, Kmart Stores 


\section{Table of Contents}

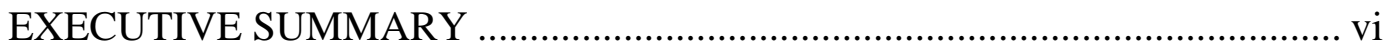

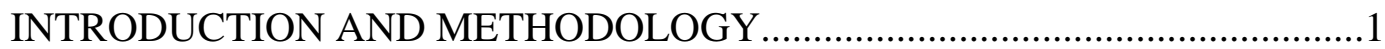

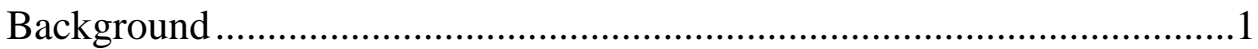

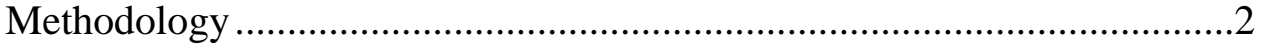

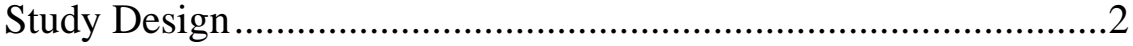

Research Tasks..............................................................................

REVIEW OF LITERATURE AND PAST CASE STUDIES ...................................

General Findings ......................................................................................

Limitations of Shared Use Park \& Rides ..........................................

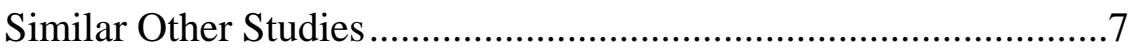

Sample Case Studies ............................................................................

Shared Park \& Ride Arrangements..................................................8

Stakeholder Coordination ...............................................................

Similar Past Research Efforts ...................................................................11

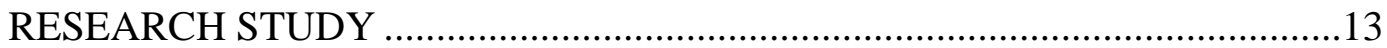

Results/Findings.....................................................................................13

Travel Characteristics ……………………………...................14

Frequency of Use ..............................................................14

Parking Yesterday/Previous Game Day...............................15

Alternative Trip Choice ......................................................16

Spending Patterns of P\&R Users ..................................................17

Purchases Made Yesterday/Previous Game Day ................17

Induced and Diverted Shipping ..........................................20

Shopping Frequency ………………………………….....22

Average Weekly Purchases..................................................23

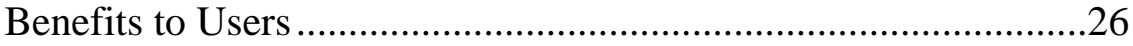

Comparative Summary With Previous Studies...........................................27

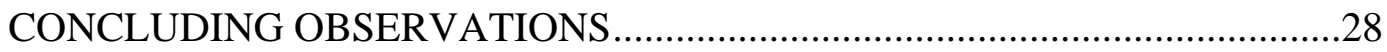

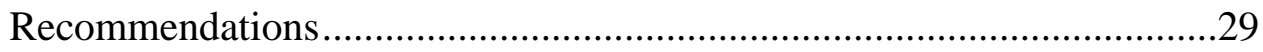

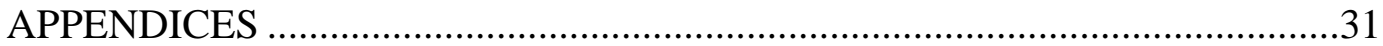

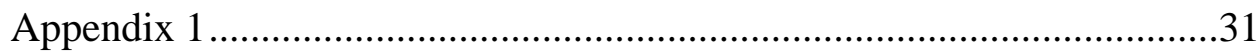

Appendix 2...................................................................................32

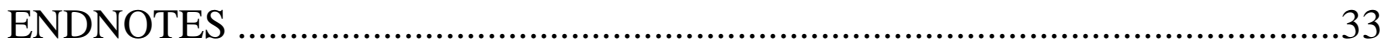




\section{EXECUTIVE SUMMARY}

According to the Urban Land Institute, shared use park and ride is defined as park and ride spaces that can be used to serve two or more individual land uses without conflict or encroachment. ${ }^{\mathrm{i}}$ It typically involves property owners allowing commuters to park personal vehicles at their parking lots to access public transit or use a carpool/vanpool to their final destinations. However, benefits of shared use park and ride facilities located at commercial retail centers have not been widely documented. Transit agencies usually perceive shared use park and ride as mutually beneficial to both the transit agency through savings in land and development costs and to park and ride providers through increases in customer sales and customer base. In contrast, potential shared use park and ride providers often feel that allowing a shared use park and ride on their property may not be cost beneficial and will bring problems such as increased liability, vandalism, and litter, and will occupy spaces that potential shoppers might have used. After an extensive review of literature, it was apparent that very little research has been done in this area since the early 1980s. This study attempts to document the impacts of shared use park and ride at retail centers by examining the following three research questions:

1. Whether the presence of a "Shared Use Park \& Ride" has influence on shopping behavior patterns of users

2. Whether the presence of a "Shared Use Park \& Ride" generates retail revenues for shared use park and ride providers

3. Whether the presence of a "Shared Use Park \& Ride" generates ridership for transit service providers

\section{Research Survey}

To provide a comparative perspective, this study design, methodology, and data analysis were modeled after the study, "Park-and-Ride at Shopping Centers: A Quantification of Modal-Shift and Economic Impacts,” by Steven Smith. ${ }^{\text {ii }}$ A survey was developed to administer to park and ride users to find out their spending habits at the businesses located nearby. This survey asked questions about frequency of use of the park and ride; reason for parking in the park and ride; alternative mode choices if the park and ride was non-existent; their shopping the previous day; alternative shopping choices if the park and ride had been non-existent; frequency of use of the stores; and amount spent at stores in an average week. An additional question was added that addressed how beneficial the availability of the park and ride has been to participants. Similarly, an adapted version of the survey was created to administer at a park and ride that was used for a special event shuttle service for the football games of a major university. The surveys were conducted at seven shared use park and rides in the following communities throughout Florida: Brandon (Hillsborough County), Tampa, Jacksonville, Ft. Lauderdale, Gainesville, and Miami.

Out of the 274 surveys completed and returned, the largest number of surveys came from the park and rides located at two shopping malls: 134 surveys came from the football shuttle park and ride, and 70 surveys came from the mall park and ride operated by a 
nearby hospital. The remaining five park and ride survey sites, which operated on a much smaller scale, were combined to provide a total of 70 surveys (hence to be referred to as "smaller park and rides").

The responses from the football shuttle park and ride were analyzed separately from the rest because they made up such a large proportion of the responses (48.9\%), and a slightly different survey form was used. The hospital shuttle was analyzed separately as well because it also made up a significant proportion of the responses (25.6\%), and was different than the smaller park and rides, in that users were regular employees commuting to work as well as hospital patients who used the park and ride less frequently. The responses from the remaining five park and ride sites were combined and analyzed together because there were a smaller number of respondents at each site, and because they had a similar set up, in which most of the users were employees commuting to work everyday.

\section{Research Findings}

The findings were broken down into three major categories: travel characteristics, spending patterns and user benefits.

\section{Travel Characteristics}

Frequency of Use: In the case of the smaller park and rides, the vast majority of the respondents (89.7\% of 68 respondents) used the park and ride five days a week. In contrast, only $22.9 \%$ of the 70 hospital shuttle respondents used the park and ride five days a week, while $48.6 \%$ used the park and ride less than one to two days a week. The majority of the respondents from the football shuttle (62.1\% of 123 respondents) indicated that they used the park and ride to get to at least $75 \%$ of the six football games, while $22.6 \%$ of the respondents indicated that they used the park and ride to get to less than $25 \%$ of the football games.

Alternate Trip Choice: When survey respondents were asked how they would have gotten to their destination if the park and ride had not been there, the most common response (49.4\% of 174 respondents overall) was "would have driven all the way to my destination." Seventy one percent of the 31 hospital shuttle respondents, $51.2 \%$ of the 86 football shuttle respondents, and $35.1 \%$ of the 57 respondents from the smaller park and rides chose this response. The impact on mode split was that $45 \%$ of the 57 smaller shared use park and ride users were diverted to transit, i.e., 35.1\% would have "driven all the way" and $10.5 \%$ would have used "other" means of travel. Similarly, $83 \%$ of the 31 respondents were diverted to the hospital shuttle and $61 \%$ of the 86 respondents to the football shuttle, which also reflects savings on parking and traffic congestion at the hospital and game venue respectively. 


\section{Spending Patterns}

In this section (and in respective sections of this report), we will use "shopper" to refer to shared use park and ride users who actually shopped at the site while "park and ride user" includes both respondents who shopped and those who did not shop at the site.

Purchases Made Yesterday/Previous Game Day: Of those respondents who had parked in the lot the previous day, $39.0 \%$ of the 59 smaller park and ride respondents and $38.7 \%$ of the 31 hospital shuttle respondents had also shopped there the previous day. Of the football shuttle respondents who used the park and ride lot on the last game day, $40.9 \%$ of the 88 respondents also shopped at the mall that day. The football shuttle park and ride had the highest average purchase (\$25.19 per shopper and \$10.31 per park and ride user), followed by the smaller park and rides (\$21.13 per shopper and \$8.24 per park and ride user), and the hospital shuttle park and ride (\$14.83 per shopper and \$5.74 per park and ride user). The "shopper" amount refers to the average amount that a park and ride user actually spent. The "park and ride user" amount includes both park and ride users who shopped and those who did not shop in calculating the average amount spent.

Induced and Diverted Shopping: Those park and ride users who indicated that they shopped the previous day were then asked what they would have done about obtaining that day's purchases if the park and ride lot had not been there. The purpose of this question was to determine whether any of the shopping was diverted, meaning the respondents would have made their purchases somewhere else if they had not parked there that day, or diverted, meaning that the respondents would not have made the purchases at all if they had not parked there that day. The results indicate that $42.9 \%$ of the 70 respondents were either diverted (22.9\%) or induced (20.0\%) shoppers, and would not have made purchases at that shopping center if the park and ride lot had not been there.

Shopping Frequency: Shopping frequency refers to the number of times respondents shop at the shopping center in a typical week/football season when using the park and ride. The overall average shopping frequency was 1.55 days per week for the smaller park and rides, 0.76 days per week for the hospital shuttle park and ride, and 1.72 game days per season for the football shuttle park and ride. The overall percentage of respondents who made purchases at the shopping center at least once a week when using the park and ride was $69.1 \%$ of 68 respondents for the smaller park and rides and $44.3 \%$ of 70 respondents for the hospital shuttle park and ride. Fifty percent of the 124 football shuttle respondents made purchases at the mall at least once a football season when using the park and ride.

Average Weekly Purchases: The smaller park and rides had a higher average weekly purchase amount (\$37.79 per shopper and \$26.12 per park and ride user) than the hospital shuttle park and ride (\$25.06 per shopper and \$12.17 per park and ride user), which can be expected since the smaller park and rides have a higher shopping frequency. The football shuttle park and ride had an average purchase amount of \$72.09 per shopper and $\$ 37.21$ per park and ride user in a typical season. As noted above, the "shopper" amount 
refers to the average amount that a park and ride user actually spent. The "park and ride user” amount includes both park and ride users who shopped and those who did not shop in calculating the average amount spent.

\section{Benefits to Users}

When asked how beneficial the availability of a park and ride had been to them, overall, $83.5 \%$ of the 249 respondents gave a rating of one (very beneficial), $6.8 \%$ gave a rating of two, $6.8 \%$ gave a rating of three, $2.0 \%$ gave a rating of four, and $0.8 \%$ gave a rating of five (not beneficial). The football shuttle park and ride had the highest response rating, with $85.7 \%$ of the 112 respondents giving a rating of one, followed by the smaller park and rides with $83.8 \%$ of 68 respondents giving a rating of one, and then by the hospital shuttle with $79.7 \%$ of 69 respondents giving a rating of one.

\section{Concluding Remarks}

The research indicates that the park and ride users at the survey sites are indeed shopping at the shopping centers when they park at the park and ride. Sixty nine percent of the 68 respondents from the smaller park and rides shopped at the shopping center at least once a week when using the park and ride, spending a weekly average of \$37.79 per shopper. Forty four percent of the 70 respondents from the hospital shuttle park and ride shopped at the shopping center at least once a week when using the park and ride spending a weekly average of $\$ 25.06$ per shopper. Fifty percent of the 124 respondents from the football shuttle park and ride shopped at least once a football season when using the park and ride, spending an average of $\$ 72.09$ per shopper each football season. These weekly averages could translate into annual expenditures of $\$ 1,965.08$ per shopper for the smaller park and rides and \$1,303.12 per shopper for the hospital shuttle park and ride. Furthermore, a significant proportion of those users would not have shopped at the retail center if the park and ride lot did not exist. Overall, $42.9 \%$ of the 70 shoppers would have either made their purchases elsewhere or not have made the purchases at all if they had not used the park and ride at that shopping center. These results show that the shared use park and rides studied actually did increase the shopping centers' customer base.

Implications of these research findings indicate that shopping centers might benefit if they are willing to allow their properties to be used for shared use park and ride. It also shows that transit agencies may be able to provide concrete research data to prove to prospective shared use park and ride providers that they will benefit financially through an increased customer base and new revenues. Transit service providers also may benefit from saved expenditures on park and ride facilities (some agencies invest in making customer-amenity improvements through a land use agreement with the property owner), increases in ridership, and customer satisfaction for providing more park and rides. Similarly, the local community benefits from access to public transit and mitigation of traffic congestion and efficient use of parking facilities.

It is important that similar research be expanded upon and conducted on a larger scale with direct transit agency involvement. This would help identify parameters for an ideal park and ride location, operational considerations and an account of all types of shared use park and ride facilities. While participation of park and ride providers would enhance 
the process further, full participation by transit agencies would allow surveys to be done at bus stops where park and ride providers are reluctant to allow surveyors on their property. Additionally, an analysis of property owners hesitant to participate in shared park and ride facilities might provide a better understanding of partnership issues and benefits. Further research in other states or at a national level will provide a better comparative picture. 


\section{INTRODUCTION AND METHODOLOGY}

The purpose of this study is to document certain economic benefits, if any, of shared use park and ride facilities located at commercial retail centers. The perceived benefits and negative impacts of shared use park and ride arrangements have long been a topic of debate. Transit agencies usually perceive shared use park and ride as mutually beneficial to both the transit agency through savings in land and development costs and the shared use park and ride providers through an increase in customer base and sales. In contrast, prospective shared use park and ride providers (such as property owners or managers) tend to hold negative perceptions about providing a shared use park and ride and are usually not enthusiastic about entering into these agreements. They often feel that allowing a shared use park and ride on their property will bring problems such as increased liability, vandalism, and litter, and will occupy spaces that potential shoppers might have used.

Little published research could be found that validated either the positive or negative perceptions held by transit agencies and shared use park and ride providers. Therefore this study attempts to document whether the existence of a shared use park and ride at a retail center actually increases the customer base of the retail center and if such a park and ride increase ridership on the transit system. A number of factors are examined, but the research attempts to answer three main research questions:

1. Whether the presence of a "Shared Use Park \& Ride" has influence on shopping behavior patterns of users

2. Whether the presence of a "Shared Use Park \& Ride" generates revenues for shared use park and ride providers

3. Whether the presence of a "Shared Use Park \& Ride" generates ridership for transit service providers

\section{Background}

In the Guide for the Design of Park-and-Ride Facilities, the American Association of State Highway and Transportation Officials define a shared use, or joint use, park and ride facility as "a parking lot used for a specific activity but also used to accommodate commuter vehicles from the beginning of the morning peak period until the end of the evening peak period.,iii Examples of where shared use park and ride facilities are often located include shopping centers, churches, recreational centers, professional sports centers, and drive-in movie theaters. Traditional park and ride facilities, on the other hand, are usually parking lots developed and owned by the transit agency or department of transportation, and used solely for the parking of commuter vehicles.

Shared use park and ride facilities can be a useful alternative to traditional park and ride facilities for several reasons. First, sharing the use of a private facility can save a considerable amount of money. ${ }^{\text {iv }}$ In some cases the private property owner allows the transit agency to share the parking spaces for free, but even if the transit agency is required to pay leasing and maintenance expenses, it is still much less costly than buying 
and developing land for a new park and ride lot. Second, shared use park and ride allows for the flexible allocation of transit service. Transit agencies are not bound to one location if customer demand or bus routes change as they would be if they had built their own park and ride lot. Third, shared use facilities have more activity and traffic during the day than traditional park and ride facilities, providing more security from theft and vandalism. Finally, a shared use park and ride facility can bring an increased presence in the community for both the transit agency and the private property, whether it is a church or a shopping center or some other type of private facility.

Although shared use park and ride has many benefits, there are also a number of challenges involved in implementing this type of arrangement. Due to possible negative perceptions and lack of awareness of potential benefits, it is often difficult to find property owners/managers who are willing to allow their property to be used for a shared use park and ride. Also, once shared use parking agreements are made, maintaining positive communication between the shared use $\mathrm{P} \& \mathrm{R}$ providers and the transit agencies is a challenge. Other issues that may arise and must be addressed include: maintenance of the site, site design to accommodate transit vehicles and customer amenities, overcoming the perceptions of theft and vandalism, and selling the positive benefits to both parties.

\section{Methodology}

\section{Study Design}

To avoid reinventing the wheel as well as providing a base line, the study design, methodology, and data analysis were modeled after the 1983 study, "Park-and-Ride at Shopping Centers: A Quantification of Modal-Shift and Economic Impacts," by Steven Smith. ${ }^{\vee}$ The Smith study was chosen because of the breadth and similarity to our questions of interest.

As already indicated, the current study attempted to answer three research questions; i.e., whether the presence of a "Shared Use Park \& Ride" has influence on shopping behavior patterns of users, whether it generates revenues for park and ride providers, and whether it generates ridership for transit service providers.

To answer these research questions, a survey was developed to administer to park and ride users to find out their spending habits at the businesses located nearby. Like the survey in Smith's study, this survey asked questions about frequency of use of the park and ride; reason for parking at the park and ride; alternative mode choices if the park and ride was non-existent; shopping the previous day; alternative shopping choices if the park and ride had been non-existent; frequency of use of the stores; and amount spent at stores in an average week. An additional question was added that addressed how beneficial the availability of the park and ride has been to the participant.

The survey questions are listed below (see appendix 1 for details):

1) Your primary purpose for using this Park \& Ride is to (check all that apply) 
2) How often do you park here?

3) Did you park here yesterday?

4) If the lot had not been here, what would you have done to get to your destination yesterday?

5) Did you shop at any of the stores here yesterday on your way to or from your destination?

6) If this lot had not been here, what would you have done about obtaining yesterday's purchases?

7) In a typical week, how many times do you shop at these stores when you park here for your trip to your destination?

8) In a typical week, how much do you spend at these stores when you park here for your trip to your destination?

9) How beneficial has the availability of Park \& Ride been to you? (Please rank).

An adapted version of the survey was created to administer at a park and ride that was used for a special event shuttle service for the football games of a major university (see appendix 2). Instead of asking questions such as how often the survey participant parked there in a given week and the amount spent in an average week, the question was rephrased to ask how often the participant parked there and how much he or she spent in an average football season.

This study builds off of a previous National Center for Transit Research (NCTR) study entitled "Commuter Choice Managers and Parking Managers Coordination."vi In this earlier study shared use park and rides throughout Florida were identified, as well as the transit agencies that operated them and the property managers of the shopping centers where the park and rides were located. During this previous research, park and ride providers were asked for permission to conduct a future park and ride user survey on their property for this current study.

This park and ride user survey was conducted at seven shared use park and rides in the following communities throughout Florida: Brandon (Hillsborough County), Tampa, Jacksonville, Ft. Lauderdale, Gainesville, and Miami. Survey sites included two shopping malls, three shopping centers, and two Kmart shopping plazas. These included big box and strip mall stores with a presence of competing retail centers. With the exception of the two shopping mall park and rides, the survey was administered at each site between 6:00 and 9:00 a.m. in an attempt to catch park and ride users on their way to work. One of the mall park and ride lots was operated exclusively for the staff and patients of a nearby hospital. The hospital operated a shuttle service that ran throughout the day between the mall and the hospital. The survey was administered at this site between 7:00 am and 2:00 pm. The other mall was used as a park and ride for a shuttle service that transported people back and forth from the mall to football games at a nearby university. This survey was administered for two hours before the game started. 
The administration of the survey was straightforward. Research staff approached the park and ride users as they departed from their vehicles and headed towards the bus stop. Park and ride users were asked to fill out a brief survey while they waited for the bus. In the event that the bus was pulling up or the rider felt there was not enough time to fill out the survey, they were given the survey with a stamped addressed envelope to mail back.

\section{Research Tasks}

To accomplish this study's objectives, five key tasks were outlined as follows:

\section{Task 1: $\quad$ Research Review}

This task involved a comprehensive review of past research into efforts to document benefits of shared use park and ride programs for primary stakeholders (i.e., service providers, ${ }^{\text {vii }}$ park and ride providers, ${ }^{\text {viii }}$ and park and ride users ${ }^{\text {ix }}$ ). This literature review identified methodologies and findings from past studies to serve as a starting point for the research and to help avoid "reinventing the wheel" and refine specific gaps and deficiencies in the existing body of knowledge. ${ }^{\mathrm{x}}$ The review included an examination of previous research conducted on benefits of park and rides to stakeholders and changing trends in the industry ${ }^{\mathrm{xi}}$. Similar other studies reviewed include arrangements of park and ride among individual institutions, shuttle programs and informal park and rides. ${ }^{\text {xii }}$

\section{Task 2: $\quad$ State of the Practice of Business Benefits Measurement}

While the current literature was very scanty, the study identified a few good quantitative surveys such as the article in the 1978 Newsletter of the Office of Highway Planning, entitled "Shopping Centers Make a Profit on Park-and-Ride, xiii a 1982 study by the Southern California Rapid Transit District (RTD) titled "Shopping Center Park \& Ride User's Survey: Lines 716, 760, 762”, xiv and a 1983 study entitled "Park-and-Ride at Shopping Centers: A Quantification of Modal-Shift and Economic Impacts.” ${ }^{\mathrm{x}}$ Each of these studies provided key insights and the basis for further study.

\section{Task 3: $\quad$ Surveys of Park and Ride Users}

This task involved the actual survey of park and ride users and was the central goal for this study. The task involved gathering information from actual park and ride users using students to intercept them as they leave or depart for the high occupancy vehicle. The research replicated the Smith study above to survey users regarding influence of park and rides on park and ride user's shopping habits, potential for revenue generation for shared use park and ride providers and potential impact on ridership for transit service providers.

\section{Task 4 \& 5: Analyses of Findings \& Reporting}

The last two tasks involved the analysis of findings (task 4) and preparation of the final report (task 5). 


\section{REVIEW OF LITERATURE AND PAST CASE STUDIES}

In late 1983, the Planning Journal published a special report written by Wilbur Smith entitled What's New in Parking, which explored parking trends, ideas, and solutions. Smith states that, "clearly the need for parking will continue to grow. Parking needs are likely to fluctuate, depending on such variables as the extent to which transit systems are improved, the health of the central business districts, and the state of local economies.” xvi

The report takes a broad look at parking based on an updated view of current developments in towns and cities, in energy, transportation, economics, environmental problems and more. The author asserts that it should come as no surprise to the casual observer of transportation and travel patterns that the private car continues overwhelmingly to be the number one choice of people for all trip purposes. According to the report, the costs of constructing and operating parking facilities of all kinds are high. Likewise, other possible barriers to building parking facilities have included finding adequate transit service, insufficient rideshare programs, lack of suitable incentives, and perceived security concerns. Fortunately, in recent years some land uses and activities have required less parking. This phenomenon is due to a combination of a jump in fuel prices, higher car operating costs, higher parking fees, and in some cases government policy.

The Wilbur Smith report notes that parking rates are also being used as tools in favor of HOVs. The study revealed that due to the high costs of parking construction and operations, the emphasis is on mixed-use projects built by the public and private sectors jointly.

A shared (or joint) use park and ride involves sharing a private parking lot with commuters, usually provided by shopping centers, churches and others. While there appears to be a growing need for park and ride facilities throughout the U.S., review of literature indicates a limited amount of research available on shared use lots and their effectiveness. There is also limited quantitative data to support or refute the benefits of shared use $\mathrm{P} \& \mathrm{R}$, including reducing traffic congestion and Vehicle Miles Traveled (VMT). Transit agencies tend to approach potential providers with emphasis on benefits to the providers including shopping, while providers tend to stress problems like liability and vandalism. In the Tampa Bay area, one mall has welcomed the program while another would not even allow a bus on the premise at its inception. Without objective research on this topic, these issues remain inconclusive.

\section{General Findings}

In a report entitled Public Transit Access to Private Property, similar research focused on the legal rights of public transit agencies to access private property as well as major concerns of private property owners relating to public transit access. ${ }^{\text {xvii }}$ To identify concerns of private property owners, written surveys were administered to public transit providers and private property owners, developers and managers. Interestingly, the surveys revealed that the perception transit agencies had regarding the concerns of park $\&$ ride providers were not the kind of incentives that park and ride providers desired. 
In a report conducted for the Urban Land Institute by Barton Associates, in 1983, shared use park and ride is defined as park and ride spaces that can be used to serve two or more individual land uses without conflict or encroachment. ${ }^{\text {xviii }}$ The authors note that shared use park and ride only works with developments that meet certain conditions:

- When there are variations in the peak accumulation of parked cars, due to the time differences inherent in the activity patterns of adjacent or mixed land uses

- When the land uses are so related that people are attracted to two or more of them on a single auto trip to the development or area such as shopping and dining at the same complex

The Federal Highway Administration report, Parking Management Tactics: A Reference Guide Volume III also contributed to the literature on conditions that must be met for shared use park and ride to be feasible. ${ }^{\text {xix }}$ These include:

- The proposed joint parking facility should be close to each participating land use

- The time periods during which each development would use the parking facility should not overlap

- There should be a legally enforceable agreement between each participating developer to ensure that the parking facility is built and operated in accordance with local zoning requirements

The 1982 Public Technology Inc., USDOT sponsored research The Coordination of Parking with Public Transportation and Ridesharing further enhanced the literature on shared use park and ride. ${ }^{\mathrm{xx}}$ The authors defined shared use park and ride as a strategy that relocates the supply of parking from the city center to outlying areas, thus eliminating the need to provide parking in the city. Likewise, the authors noted that automobiles are used primarily for collection in low-density residential areas, while express buses, rapid transit, or shuttle services are used to complete the trips.

Finding appropriate lot locations for this approach is difficult. Consequently, practitioners prefer to use existing parking facilities at churches, community centers, and shopping centers rather than building a new parking facility. This is especially true since the cost of using existing parking lots is cheaper than creating a new park and ride facility, typically ranging from $\$ 7,000$ to $\$ 25,000$ per parking space depending on the location and type of structure.

The Federal Highway Administration report, Parking Management Tactics Volume III: A Reference Guide, contributes to the literature with their synopsis of criterion for a successful lease agreement. ${ }^{\text {xxi }}$ The authors assert that upon approaching the private property owners/managers, the lead-planning agency should have a preliminary policy for reimbursing or sharing some of the costs with the landowners. This would aid in alleviating the idea of adverse impacts to the private property and assuage the 
owners/managers fear of incurring additional cost of maintenance, operation, enforcement, insurance and related costs.

\section{Limitations of Shared Use Park and Ride}

The Public Technology Inc. report, The Coordination of Parking with Public Transportation and Ridesharing, ${ }^{\text {xxii }}$ asserts that despite the benefits that can arise from the shared use park and ride approach, several factors can diminish its benefits. Consequently, these factors must be analyzed prior to establishment. These include:

- Conflict between potential park and ride patrons and other users

- Local environmental concerns

- Existing traffic and travel hazards

Similarly, an FHWA report noted that use of shared use P\&R is intended to lessen duplication of parking supply and optimize the use of existing and new parking facilities. Yet despite its benefits, this report also identified limitations. ${ }^{\text {xxiii }}$

- There are few instances where no conflicts exist in peak hours of parking for two or more uses

- There should be no long distances between the lot and one or more of the developments

- Enforcement of the joint use agreement through a land use covenant might scare off potential participants

The study by the Urban Land Institute also asserts that shared use park and ride has limitations. ${ }^{\text {xxiv }}$ In their report, the authors studied the parking space demand characteristic of each component of mixed-use development and then estimated the effects on demand that occurred by combining these uses and eliminating duplications. Parking space demand characteristics for individual land uses (office, retail, restaurant, cinema, residential, hotel) were established to represent the maximum parking accumulation occurring on a given day. This relationship was displayed through hourly accumulation curves. The peak unit demand, hourly accumulation, and seasonal variation for each of the uses were examined. They concluded that the zoning code language does not cover all of the uses.

\section{Similar Other Studies}

Besides the literature focusing on park and ride arrangements, this study also reviewed literature on issues surrounding public transit access to commercial shopping centers including capital projects arrangements between commercial shopping centers and public transportation providers. Two major sources included a study by the Center for Urban Transportation Research (CUTR) entitled "Public Transit Access to Private Property"xxv and the Florida Department of Transportation (FDOT) "State Park and Ride Lot Program Planning Manual.”xxvi The CUTR study entitled "Public Transit Access to Private 
Property," focused on the legal rights of public transit agencies to access private property as well as major concerns of private property owners relating to public transit access.

The FDOT study developed a planning manual for State Park \& Ride Lots and described the various techniques for involving the private sector in the development and operation of park and ride facilities. The manual catalogs fifteen techniques.

\section{Sample Case Studies}

Beyond general literature about shared use park and ride arrangements, this study searched for innovative case studies of shared use park and rides along with previous studies that attempted to document outcomes from shared use park and ride arrangements.

\section{Shared Park and Ride Arrangements}

Shared use park and ride arrangements can take on many forms. Transit agencies and park and ride providers can have informal verbal agreements or formal written agreements with each party having varying levels of responsibility for such things as maintenance, clean up, insurance, and installation of amenities and signage. In some cases transit agencies lease the parking spaces from park and ride providers, and in other cases the transit agencies are allowed free use of the spaces. The following is a sample of examples from three transit agencies that have taken innovative approaches to shared use park and ride.

In Portland, Oregon, the Tri-Met Park and Ride Policy Report for January 15, 2001 addresses guidelines that the agency should utilize in the implementation of park and ride and shared use park and ride. ${ }^{\text {xxvii }}$ The report suggests that despite the fact that landowners may seek reimbursement, the agency should utilize onetime operating cost construction and enhancements or tax breaks and avoid annual operating cost in operating shared use park and ride. To reduce the possibility of negative impacts on landowners, intermingling between park and ride users and non-users should be discouraged. Annual operating cost can include periodic or ongoing landscape maintenance, pavement repair, lighting and electricity, maintenance of signs and pavement markings, periodic or ongoing sweeping and garbage collection, security, advertising trade or promotions and additional liability insurance. Other possible incentives that can be utilized if the total cost does not exceed the one-time operating cost construction include installation of lighting, paving, installation of landscape, slurry seal, additional signage, and pavement markings.

King County Metro in the state of Washington has two different shared use park and ride programs. ${ }^{\text {xxviii }}$ Their more traditional Leased Park-and-Ride Program leases parking spots, primarily from churches, that are otherwise unused during commuter hours. King County provides the signs and the insurance, and the property owner is paid a small sum of money and is responsible for maintaining 
the lot. This program has been very successful. Many churches are glad to participate, seeing the program as a way to advertise their presence and give back to the community, as well as offset some operating expenses. Their newer program, the Shop \& Ride Program, partners commuters with local retail establishments. Each month, the commuter is required to purchase a small amount of merchandise (predetermined by the retail establishment), and in turn is provided with a parking space to use while commuting by bus, carpool, or vanpool. This arrangement ensures that all those involved (the transit agency, the retail establishment, and the commuters) benefit.

Pace Suburban Bus Service, which serves Chicago's six-county suburban region, takes a different approach to shared use P\&R for their vanpools. ${ }^{\text {xxix }}$ Pace has made a conscious decision not to be involved in negotiating deals with shopping centers in order to avoid inflated "rental rates" that would be charged to Pace for use of the spaces. Instead, they have the actual vanpool group itself contact a shopping center as a "regular customer" who already shops there and would like to utilize a few outlying parking lot spaces as a meeting space for their vanpool group. This approach has been very successful. Pace has found that, in general, the shopping centers are more than willing to work with "a customer" at no charge. Pace recommends, however, that its riders do not approach regional shopping centers, but rather concentrate on shopping centers that are more "neighborhood-focused," such as a strip center, Target or Wal-Mart, or even a local grocery store. These types of establishments tend to offer a higher degree of success.

\section{Stakeholder Coordination}

It is important to note that this current research builds off of an earlier study entitled "Commuter Choice Managers and Parking Managers Coordination,” from the National Center for Transit Research (NCTR) Public Transportation Synthesis Series. ${ }^{\text {xxx }}$ Through feedback from stakeholders and a review of the existing literature, this earlier study investigated the level of coordination between transit agencies and park and ride providers involved in shared use park and ride arrangements (the current study takes the earlier research a step further, by surveying the actual users of shared use park and ride to determine their spending habits at nearby businesses).

In regard to the level of coordination between transit agencies and park and ride providers and their perceptions, the literature revealed three key themes. First, most of the property owners' concerns are related to the physical attributes of the transit vehicles and the potential damage they can cause. Second, maintenance is one of the most important incentives to property managers, and also one of the most frequently offered incentives by transit agencies. Therefore, this should be a focus area when negotiating agreements. Finally, there is need for education among the stakeholders involved in order to lessen some of the misperceptions of transit services and patrons. 
In addition to the literature review, the stakeholder coordination study conducted surveys and interviews with the transit service providers and park and ride providers in Florida to solicit feedback about their perceptions and experiences with shared use park and ride, the importance of offering incentives, and lessons learned from such arrangements. Feedback from park and ride providers indicated that major concerns about shared use park and ride include perceived high levels of crime, ridership that was not part of their customer base, and damage to asphalt. The park and ride providers also identified that installation of amenities and concrete pads, maintenance of stops on site, and periodic cleanings were the most important incentives that could be offered by transit agencies.

Feedback from transit agencies indicated that park and ride providers were more inclined to cooperate with the transit agencies when assured of more prospective customers. Also, it was discovered that transit agencies may be reluctant to approach park and ride providers due to fear that they would say no or renege on past agreements.

Therefore two key issues appear when studying the coordination between transit agencies and park and ride providers. First, there are differing perceptions among transit agencies and park and ride providers. Traditionally, property managers of retail centers have not been eager about participating in a shared use park and ride arrangement because of negative perceptions that allowing a park and ride on their property may create potential for criminal activities, lead to increased insurance liability, and take away parking spaces from customers. Conversely, transit agencies tend to view this type of arrangement as having a potential economic benefit to the property managers through an increased customer base and the transit agencies themselves through savings in land and development costs, as well as providing customers and the community with the benefit of improved transit service and shopping convenience.

The second issue is a lack of communication between stakeholders. Communication is often nonexistent or limited between transit agencies and park and ride providers. To make this problem worse, management and ownership of retail properties has a high turnover rate. In many cases, transit agencies make an agreement/contract with park and ride providers but are unaware when ownership or management changes later. Park and ride agreements often "get lost in the cracks" when properties change hands, especially if the agreement was verbal. This predicament is worsened when transit service providers become reluctant to open up communication due to fear of new management reneging on the contract. In these cases, new management usually does not know a park and ride exists on the property. 
Based on the stakeholder coordination research, the authors drew a number of conclusions. First, private property owners are reluctant to participate due to several negative misperceptions that exist about transit service and transit customers. These misconceptions must be refuted and overcome. Secondly, the most effective approach to solicit private property owners' participation is to appeal to their own self-interest, as opposed to an appeal to a sense of civic responsibility. And finally, transit agencies need to address the concerns of the park and ride providers.

The authors also recommended using the following guidelines when implementing shared use park and ride:

- Provide evidence of potential benefits to park and ride providers in terms of an increased customer and work pool.

- Service providers should offer incentives including maintenance, cleaning and insurance.

- Involve park and ride providers in the development and design of routing and amenities near and within their properties.

- Try to get the government to offer incentives through reduction of developer parking requirements if the park and ride providers are willing to participate.

- Sign an agreement outlining responsibilities.

\section{Similar Past Research Efforts}

As mentioned before, search of the current literature revealed little information about shared use park and ride at retail centers. Little has been done to document or quantify the effects of park and ride facilities at businesses. However, two quantitative surveys from the early 1980's appear to show financial benefits for businesses.

The first study, entitled “Shopping Center Park and Ride Users' Survey: Lines 716, 760, 762,” was published in 1982 by the Southern California Rapid Transit District (RTD). ${ }^{\text {xxi }}$ In this study, users were surveyed at park and ride lots located at three shopping centers in the Los Angeles area: Fallbrook Square, Eastland Shopping Center, and Puente Hills Mall. The survey addressed frequency of use of the park and ride, frequency of use of the shopping center, activities engaged in during last visit to the shopping center, mean amount spent per capita on last visit, type of bus fare paid, frequency of using other RTD bus lines, use of RTD buses on weekends and evenings, demographics of riders, household income, number of cars in household, and home zip code of riders. The study found that RTD park and ride patrons used shopping center services a median of 4.3 times a month and tended to use multiple services while they were there. Shopping was the most frequently cited reason for the last visit to the shopping center (89\%), but one third also used an eating establishment, one tenth used an entertainment facility, and one sixth used other services provided at the shopping center (e.g. bank, dry cleaners, etc). The average amount spent per person on all services used during the last visit to the shopping center was $\$ 46.79$. 
The second study, which the current study is trying to replicate, took place in 1983 in Montgomery County, Maryland, and was documented in an article entitled "Park-andRide at Shopping Centers: A Quantification of Modal-Shift and Economic Impacts," published in 1983 by M. Laube and B. Dansker and written by Steven A. Smith. ${ }^{\text {xxxii }}$ The study surveyed users at Montgomery Mall and Wheaton Plaza, which were both designated as formal park and rides, and Aspen Hill Shopping Center, which had an informal agreement. The survey addressed issues of frequency of use of the park and ride; reason for parking in the park and ride; alternative mode choices if the park and ride was non-existent; shopping the previous day; alternative shopping choices if the park and ride had been non-existent; frequency of use of the stores; and amount spent at stores in an average week. Forty four percent at Aspen Hill, 42\% at Montgomery Mall and 25\% at Wheaton Plaza indicated that they shopped at the shopping center. While not proven, it was interesting to note that Aspen Hill, where the parking spaces were closer to the stores, experienced a higher percentage rate while Wheaton Plaza, whose parking was further from the stores, experienced a low percentage of patrons. The same pattern was evident in expenditures. The average purchases were \$14.10 at Aspen Hill, \$25.26 at Montgomery Mall and \$16.30 at Wheaton Plaza. Using a proportionate estimation, the study concluded that the average daily amount spent per P\&R user for Aspen Hill was \$6.20, \$10.61 for Montgomery Mall and \$4.08 for Wheaton Plaza.

Furthermore, when asked about alternative shopping choices if the park and ride was non-existent, the majority of the respondents (45\% to $61 \%$ ) indicated that they would have shopped at a different location, while $12 \%$ to $22 \%$ indicated that they would not have made the purchase. The study contends that there can be a significant economic benefit to shopping center operators for allowing commuter parking to occur on their parking lot. The survey results indicated that between $25 \%$ and $45 \%$ of the park and riders shopped at the shopping center, and two thirds of these shoppers were induced or diverted from other shopping locations. Moreover, the presence of park and ride activity caused an average $\$ 5$ increase in sales per park and ride user per day. Thus, as long as there is adequate parking supply for all customers, benefits will be derived by the shopping center operators. Commuters will benefit since work and shopping trips are easily linked. Likewise, the public benefits since there is a reduced need for additional parking facilities and reduced vehicle travel. 


\section{RESEARCH STUDY}

Currently, several transit service providers rely on their own park and ride facilities, shared use park and rides, or the state park and ride lots, especially for transit and rideshare service. However, information in this area, particularly on shared use park and rides in Florida, appears to be none existent. The most comprehensive compilation of useful information currently includes a procedures manual for the state park and ride lot program, a regional Park and Ride Lot Plan for FDOT District $7^{\text {xxxiii }}$ and the recent stakeholder coordination study. ${ }^{\text {xxxiv }}$ This research strived to quantify the level of benefits relative to costs based on feedback from commercial area shared use park and ride users. The results from this study will benefit both transit service providers and park and ride providers by increasing the potential for improving their customer service and customer base, respectively while enhancing their determination of the feasibility for making such arrangements.

\section{Results/Findings}

In all, 274 surveys were completed and returned. The largest number of surveys came from the park and rides located at the two shopping malls: 134 surveys came from the football shuttle park and ride, and 70 surveys came from the mall park and ride operated by the nearby hospital. The remaining five park and ride survey sites, which operated on a much smaller scale, were combined to provide a total of 70 surveys. Because of the small sample of park and rides that were willing to participate and because it is unknown how many people typically use these park and rides on any given day, it cannot be concluded whether or not this data is large enough to be statistically significant.

In order to avoid an inaccurate representation of the data, 12 of the 274 surveys were left out of the data analysis in cases where the answers were unclear or conflicted with other answers. For example, instead of answering certain questions with a numerical answer, such as the number of times a week they shop at the shopping center when using the park and ride, some respondents gave answers such as "a lot" or "sometimes." In other cases, the respondents gave conflicting responses, such as answering in one question that they shopped at the shopping center an average of 0 times a week, but then answering in the next question that they spent an average of $\$ 25$ a week at the shopping center. Ten of the 12 surveys left out of the data analysis came from the football shuttle park and ride and the remaining two came from the smaller park and rides. It is unclear why such a large proportion of the eliminated responses came from the football shuttle park and ride. One possible explanation is that there were significantly more respondents at this park and ride, which increases the chances of receiving faulty data.

The survey responses for each question are broken down into three categories determined by survey site type: first, the five smaller park and rides combined together; second, the hospital shuttle park and ride; and third, the football game shuttle park and ride. The responses from the football shuttle park and ride were analyzed separately from the rest because they made up such a large proportion of the responses (48.9\%), and a slightly different survey form was used. The hospital shuttle was analyzed separately as well because it also made up a significant proportion of the responses (25.6\%), and was 
different than the smaller park and rides, in that users were regular employees commuting to work as well as hospital patients who used the park and ride less frequently. The responses from the remaining five park and ride sites were combined and analyzed together because there were a smaller number of respondents at each site, and because they had a similar set up, in which most of the users were employees commuting to work everyday (hence forth referred to as smaller park and ride).

It should be noted that not all of the respondents answered every question, so the total number of responses to each question will be different. It should also be noted that all of the survey participants used the park and ride to ride transit to their destination. None of the participants parked in the parking lot to catch a carpool or vanpool.

\section{Travel Characteristics}

\section{Frequency of Use}

Table 1 displays the frequency of use of the park and rides. In the case of the smaller park and rides, the vast majority of the respondents (89.7\% of 68 respondents) used the park and ride five days a week. In contrast, only $22.9 \%$ of the 70 hospital shuttle respondents used the park and ride five days a week, while $48.6 \%$ of the 70 respondents used the park and ride less than one to two days a week. One possible reason the frequency of use is so much lower for the hospital shuttle than the smaller park and rides is that a large proportion of the hospital shuttle riders are patients who only use the shuttle to come to doctor appointments, whereas those who use the smaller park and rides are more likely to be using the park and ride to commute to work everyday. The majority of the respondents from the football shuttle (62.1\% of 123 respondents) indicated that they used the park and ride to get to at least $75 \%$ of the six home football games during the season, while $22.6 \%$ respondents indicated that they used the park and ride to get to less than $25 \%$ of the football games. When looking at frequency of use of the football shuttle, it is important to note that a significant number of the respondents were out of state visitors who were fans of the opposing team, and probably only attended one football game each season.

\section{Table 1}

\section{How often do you park here?}

\begin{tabular}{|c|c|c|c|c|c|c|}
\hline \multirow[b]{2}{*}{ Frequency } & \multicolumn{2}{|c|}{ Smaller P\&R's } & \multicolumn{2}{|c|}{ Hospital Shuttle } & \multicolumn{2}{|c|}{ Total } \\
\hline & No. & Percent & No. & Percent & No. & Percent \\
\hline a. 5 days/week & 61 & $89.7 \%$ & 16 & $22.9 \%$ & 77 & $55.8 \%$ \\
\hline b. 3-4 days/week & 4 & $5.9 \%$ & 5 & $7.1 \%$ & 9 & $6.5 \%$ \\
\hline c. 1-2 days/week & 0 & $0.0 \%$ & 15 & $21.4 \%$ & 15 & $10.9 \%$ \\
\hline d. less than that & 3 & $4.4 \%$ & 34 & $48.6 \%$ & 37 & $26.8 \%$ \\
\hline Total & 68 & & 70 & & 138 & \\
\hline
\end{tabular}




\begin{tabular}{lcc} 
& \multicolumn{2}{c}{ Football Shuttle } \\
\cline { 2 - 3 } Frequency & No. & Percent \\
\cline { 2 - 3 } a. 75\% of games & 77 & $62.1 \%$ \\
b. $\mathbf{5 0 - 7 5 \% \text { of games }}$ & 6 & $4.8 \%$ \\
c. $\mathbf{2 5 - 5 0 \% \text { of games }}$ & 12 & $9.7 \%$ \\
d. less than 25\% & 28 & $22.6 \%$ \\
Total & 123 &
\end{tabular}

Implicit impacts of these findings include increase in transit ridership along with mitigation of traffic congestion and parking problems at park and ride users' destination sites. Each user of shared use park and ride saves an additional trip on local roads and parking facilities.

\section{Parking Yesterday/Previous Game Day}

Table 2 indicates how many of the respondents parked at the park and ride the previous day, or the previous game day in the case of the football shuttle park and ride. Over 86\% of the 68 respondents from the smaller park and rides used the park and ride the previous day, $44.3 \%$ of the 70 hospital shuttle respondents used the park and ride the previous day, and $74.4 \%$ of the 121 football shuttle respondents used the park and ride the previous game day.

The percentage of hospital shuttle respondents who used the park and ride the previous day is significantly lower than the percentages from both the smaller park and rides and the football shuttle park and ride. As explained in the previous section, a large proportion of the hospital shuttle riders are patients who only use the shuttle to come to doctor appointments, thereby making it less likely that they would have used the shuttle the previous day.

Table 2

Did you park here yesterday?

\begin{tabular}{|c|c|c|c|c|c|c|}
\hline \multirow{2}{*}{$\begin{array}{l}\text { Park here } \\
\text { yesterday? }\end{array}$} & \multicolumn{2}{|c|}{ Smaller P\&R's } & \multicolumn{2}{|c|}{ Hospital Shuttle } & \multicolumn{2}{|c|}{ Total } \\
\hline & No. & Percent & No. & Percent & No. & Percent \\
\hline a. Yes & $\overline{59}$ & $86.8 \%$ & $\overline{31}$ & $44.3 \%$ & 90 & $65.2 \%$ \\
\hline b. No & 9 & $13.2 \%$ & 39 & $55.7 \%$ & 48 & $34.8 \%$ \\
\hline Total & 68 & & 70 & & 138 & \\
\hline
\end{tabular}

\section{Football Shuttle}

Park here

last game? No. Percent

\begin{tabular}{|c|c|}
\hline a. Yes & 90 \\
\hline b. No & 31 \\
\hline Total & 121 \\
\hline
\end{tabular}




\section{Alternate Trip Choice}

As detailed in Table 3 and Figure 1 below, when the survey respondents were asked what they would have done to get to their destination the previous day if the park and ride lot had not existed, the most common response (49.4\% of 174 respondents overall) was "would have driven all the way to my destination." Seventy one percent of the 31 hospital shuttle respondents, $51.2 \%$ of the 86 football shuttle respondents, and $35.1 \%$ of the 57 respondents from the smaller park and rides chose this response. The second most common response (25.9\% of 174 respondents overall) was "would have parked nearby (within walking distance) and caught the same bus,” followed by (13.8 \% of 174 respondents overall) "would have caught the bus somewhere else." The results indicate that the existence of a park and ride induced a modal shift from automobile trips to using transit for almost half of the respondents. However, in the case of both the hospital shuttle and the football shuttle, it is probable that lack of other bus stops along the route between the park and ride and the final destination may have influenced riders to perceive that they did not actually have the hypothetical option of catching the same bus somewhere else. This may explain why significantly more respondents from the hospital and football shuttles than from the smaller park and rides indicated that they would have driven all the way to their destination if the park and ride lot had not been there.

\section{Table 3}

If the lot had not been here, what would you have done to get to your destination yesterday?

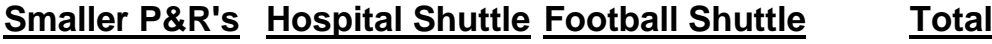

\begin{tabular}{|c|c|c|c|c|c|c|c|c|}
\hline $\begin{array}{l}\text { Alternate Trip Choice (would } \\
\text { have...) }\end{array}$ & No. & Percent & No. & Percent & No. & Percent & No. & Percent \\
\hline a. parked nearby & 17 & $29.8 \%$ & 4 & $12.9 \%$ & 24 & $27.9 \%$ & 45 & $25.9 \%$ \\
\hline b. caught bus elsewhere & 14 & $24.6 \%$ & 1 & $3.2 \%$ & 9 & $10.5 \%$ & 24 & $13.8 \%$ \\
\hline c. driven all the way & 20 & $35.1 \%$ & 22 & $71.0 \%$ & 44 & $51.2 \%$ & 86 & $49.4 \%$ \\
\hline d. other & 6 & $10.5 \%$ & 4 & $12.9 \%$ & 9 & $10.5 \%$ & 19 & $10.9 \%$ \\
\hline Total & 57 & & 31 & & 86 & & 174 & \\
\hline
\end{tabular}


Figure 1

Alternate Trip Choice if Lot Had Not Been There (would have...)

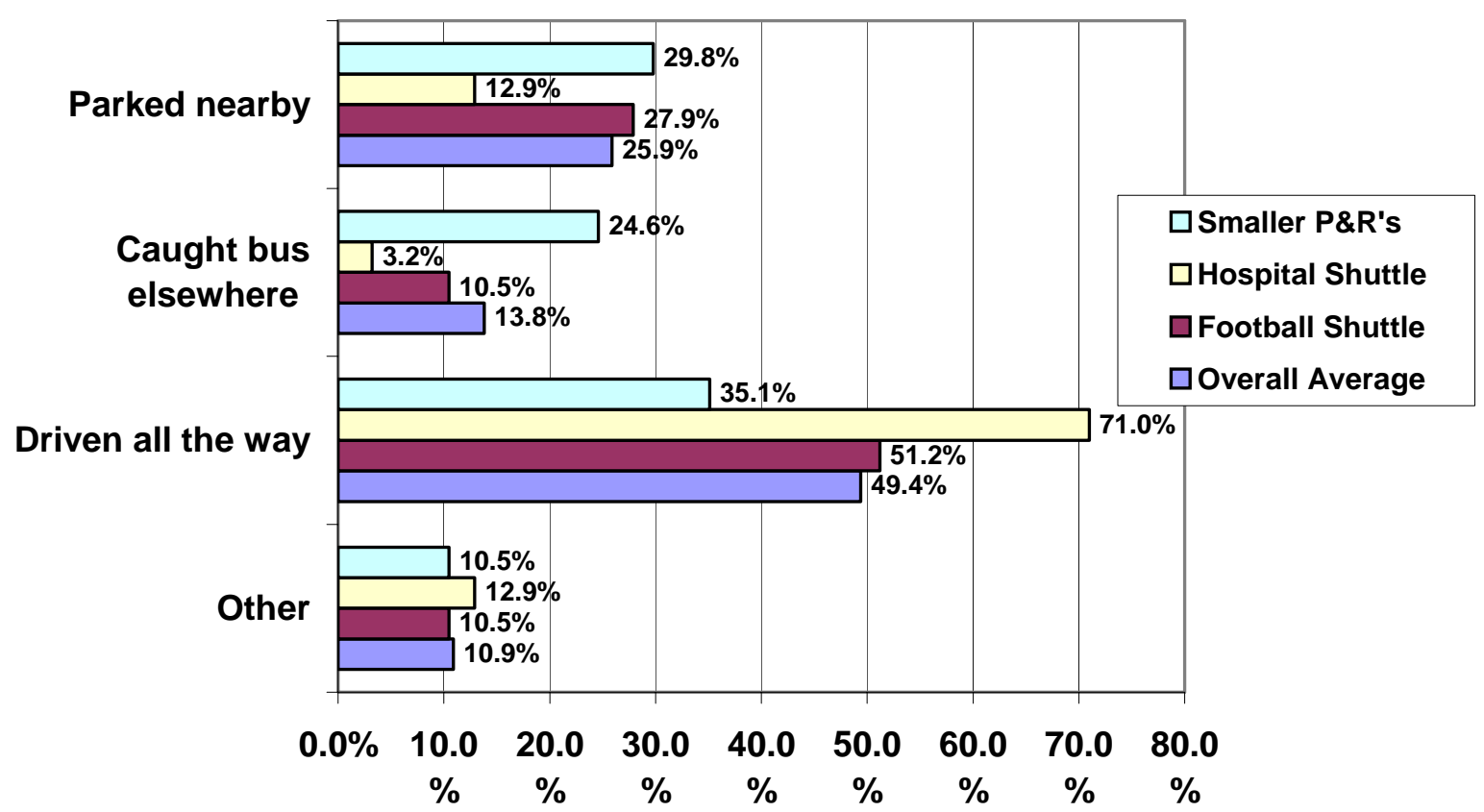

Implicit in these findings is the impact on mode split of $45 \%$ of the 57 smaller shared use park and ride users diverted to transit, i.e., 35.1\% would have "driven all the way" and $10.5 \%$ would have used "other”. Similarly, $83 \%$ of the 31 respondents were diverted to the hospital shuttle and $61 \%$ of the 86 respondents to the football shuttle, which also reflects savings on parking and traffic congestion at the hospital and game venue respectively.

\section{Spending Patterns of Park and Ride Users}

\section{Purchases Made Yesterday/Previous Game Day}

Table 4 indicates how many of those respondents who parked at the park and ride lot the previous day, or the previous game day in the case of the football shuttle park and ride, also shopped at the adjacent shopping center on the way to or from their destination that day. Responses were proportionately similar across the board. Of those respondents who had parked in the lot the previous day, 39.0\% of the 59 smaller park and ride respondents and $38.7 \%$ of the 31 hospital shuttle respondents had also shopped there the previous day. Of the football shuttle respondents who used the park and ride lot on the last game day, $40.9 \%$ of the 88 respondents also shopped at the mall that day. 


\section{Table 4}

Did you shop at any of the stores here yesterday on your way to or from your destination?

\begin{tabular}{|c|c|c|c|c|c|c|}
\hline \multirow[b]{2}{*}{$\begin{array}{l}\text { Shop here } \\
\text { yesterday? }\end{array}$} & \multicolumn{2}{|c|}{ Smaller P\&R's } & \multicolumn{2}{|c|}{ Hospital Shuttle } & \multicolumn{2}{|c|}{ Total } \\
\hline & No. & Percent & No. & Percent & No. & Percent \\
\hline a. yes & $\overline{23}$ & $39.0 \%$ & $\overline{12}$ & $38.7 \%$ & $\overline{35}$ & $38.9 \%$ \\
\hline b. no & 35 & $59.3 \%$ & 19 & $61.3 \%$ & 54 & $60.0 \%$ \\
\hline no response & 1 & $1.7 \%$ & 0 & $0.0 \%$ & 1 & $1.1 \%$ \\
\hline Total & 59 & & 31 & & 90 & \\
\hline
\end{tabular}

\section{Football Shuttle}

Shop here

last game? No. Percent

a. yes $\quad \frac{10}{36} \quad 40.9 \%$

b. no $\quad 49 \quad 55.7 \%$

no response $3 \quad 3.4 \%$

Total 88

Table 5 and Figure 2 indicate the average amount spent on purchases the previous day or game day. The average purchase amount is calculated per shopper, as well as per park and ride user that day. The "shopper" refers to the average amount that a park and ride user actually spent. The "park and ride user" includes both park and ride users who shopped and those who did not shop in calculating the average amount spent. For each category, the sum of all the purchases made was divided by the number of respondents who shopped there that day and then by the total number of respondents who parked at the park and ride that day. The football shuttle park and ride had the highest average purchase (\$25.19 per shopper and \$10.31 per park and ride user), followed by the smaller park and rides (\$21.13 per shopper and \$8.24 per park and ride user), and the hospital shuttle park and ride (\$14.83 per shopper and \$5.74 per park and ride user).

\section{Table 5}

If yes, about how much did you spend?

Smaller P\&R's

Avg. Amount Spent Yesterdayl Last Game
Per $\quad$ Per P\&R

\begin{tabular}{l}
\multicolumn{3}{c}{ Smaller P\&R's } \\
No. Shopper \\
No. $\underline{\text { Per P\&R }}$
\end{tabular}

23

$\$ 21.13 \quad 59 \quad \$ 8.24$
Hospital Shuttle

Per Per P\&R

No. Shopper No. User

$12 \quad \begin{array}{llll}14.83 & 31 & \$ 5.74\end{array}$ 


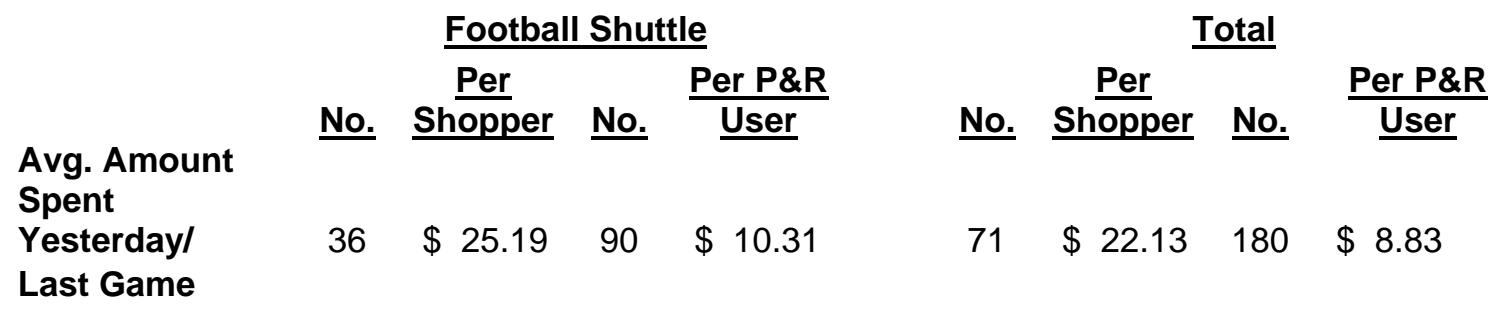

Figure 2

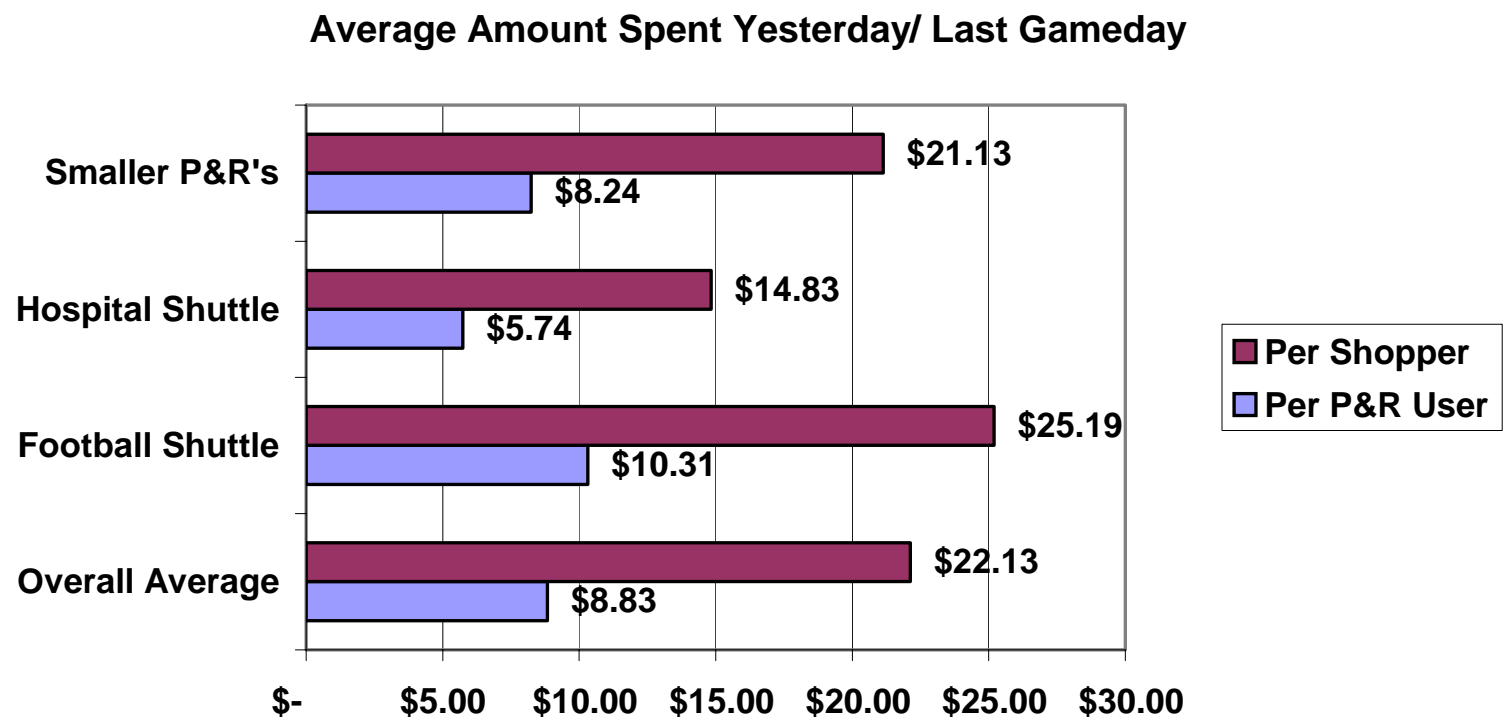

Alternative Analysis

It is important to note that the actual averages for amount spent are probably higher than the calculated averages, because 31 out of the 71 respondents who indicated that they had shopped there yesterday or the previous game day did not indicate how much they spent that day. Because those respondents left that question blank, their individual purchase amounts were computed into the first calculation as $\$ 0.00$. If those respondents who left the purchase amount blank are left out of the calculation for the average purchase amount, then the average purchase amounts are significantly higher. (See Table 6 below.) With the second calculation the average purchase amount increases from $\$ 21.13$ to $\$ 30.37$ per shopper for the smaller park and rides, from \$14.83 to $\$ 25.43$ per shopper for the hospital shuttle park and ride, and from \$25.19 to \$53.35 per shopper for the football shuttle park and ride. 


\section{Table 6}

If yes, about how much did you spend?

\begin{tabular}{|c|c|c|c|c|}
\hline & $\begin{array}{l}\text { Smaller P\&R'S } \\
\text { Per Shopper }\end{array}$ & $\frac{\frac{\text { Hospital }}{\text { Shuttle }}}{\text { Per }}$ & $\frac{\frac{\text { Football }}{\text { Shuttle }}}{\text { Ser }}$ & $\frac{\text { Total }}{\text { Sher }}$ \\
\hline $\begin{array}{l}\text { Avg. Amount } \\
\text { Spent Yesterdayl } \\
\text { Last Game }\end{array}$ & 30.37 & 25.43 & $\$ 53.35$ & $\$ 39.27$ \\
\hline
\end{tabular}

It is not clear why so many of the respondents indicated that they shopped the yesterday or the previous game day, but then left the purchase amount blank. It is possible that the respondents could not remember how much they spent that day or that the failure to provide a purchase amount is an indicator that no shopping actually occurred. Another possibility is that the respondents left the purchase amount blank because they were in a hurry and wanted to finish the survey quickly. In any case, it cannot be assumed that a blank purchase amount means that no money was spent at the shopping center that day. Therefore, a third calculation of the average purchase amount was done by replacing the \$0.00's of those shoppers who left the purchase amount blank with average purchase amounts from the first calculation. For example, for the smaller park and rides group the shoppers who left yesterday's purchase amount blank would be counted as having spent $\$ 21.13$ (the smaller park and ride group's average from the first calculation) rather than $\$ 0.00$. When using this calculation, the average purchase amount per shopper is $\$ 27.56$ for the smaller park and rides, \$20.18 for the hospital shuttle park and ride, and \$38.43 for the football shuttle park and ride. (See Table 7).

\section{Table 7}

\section{If yes, about how much did you spend?}

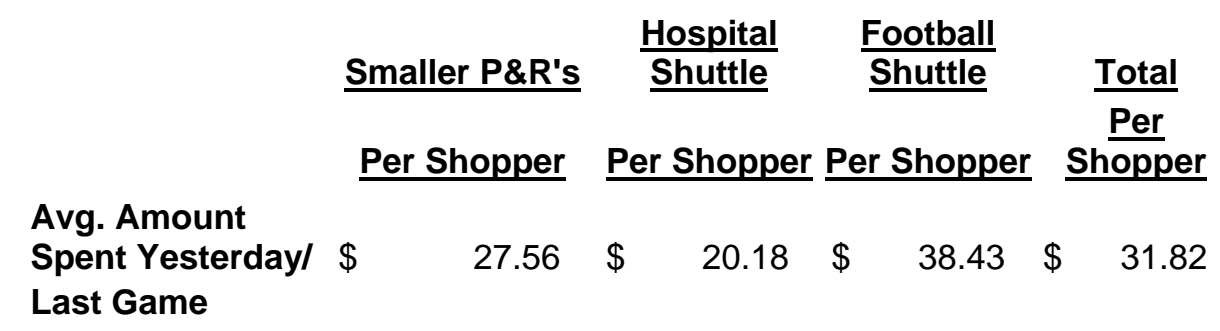

\section{Induced and Diverted Shopping}

After indicating whether they made purchases at the shopping center the previous day or game day and the amount spent, the park and ride users were then asked what they would have done about obtaining that day's purchases if the park and ride lot had not been there. The purpose of this question was to determine whether the existence of the park and ride lot actually increased the shopping center's customer base. It is possible that the park and ride users who shopped at the shopping center that day would have made their purchases 
there regardless of whether or not they had parked in the park and ride lot, in which case the existence of the park and ride lot would not financially benefit the shopping center. Asking this hypothetical question helps establish two things. First, whether the shopping that occurred was diverted, meaning that the survey respondents would have made their purchases somewhere else if they had not parked there that day. And second, whether the shopping was induced, meaning that the survey respondents would not have made the purchases at all if they had not parked there that day.

Please note, some of the responses for this question were taken out of the data analysis in cases where the respondents indicated that they did not shop at the shopping center yesterday, but still answered the question of what they would have done about obtaining that day’s purchases if the park and ride lot had not been there.

As detailed in Table 8 and Figure 3, overall the most common response was would have "bought the same things at this location on the way to or from my destination" (34.3\% of 70 respondents overall), followed by would have "bought the same things at a different location" (22.9\% of 70 respondents overall), would have "not bought the things" $(20.0 \%$ of 70 respondents overall), and would have "bought the same things at this location at a different time” (18.6\% of 70 respondents overall). (See table below.) However, these results indicate that $42.9 \%$ of the 70 respondents were either diverted $(22.9 \%)$ or induced (20.0\%) shoppers, and would not have made purchases at that shopping center if the park and ride lot had not been there.

Responses varied quite significantly when looking at each group individually. The smaller park and rides had the highest percentage of respondents who were diverted shoppers (39.1\% of 23 respondents), whereas the hospital shuttle had a highest percentage of induced shoppers (58.3\% of 12 respondents). The football shuttle had the highest percentage of respondents who said they would have made their purchases either at the same location at the same time (42.9\% of 35 respondents) or at the same location at a different time (20.0\% of 35 respondents).

\section{Table 8}

\section{If this lot had not been here, what would you have done about obtaining yesterday's purchases?}

$\frac{\text { Smaller }}{\underline{\text { P\&R's }}} \quad \underline{\text { Hospital }} \quad \underline{\text { Football }} \quad \underline{\text { Shuttle }} \quad \underline{\text { Total }}$

Alternate Purchase (would have shopped...)

\begin{tabular}{ccccccccc}
\hline & No. & Percent & No. & Percent & No. & Percent & No. & Percent \\
\hline 8 & $34.8 \%$ & 1 & $8.3 \%$ & 15 & $42.9 \%$ & 24 & $34.3 \%$ \\
4 & $17.4 \%$ & 2 & $16.7 \%$ & 7 & $20.0 \%$ & 13 & $18.6 \%$ \\
9 & $39.1 \%$ & 2 & $16.7 \%$ & 5 & $14.3 \%$ & 16 & $22.9 \%$ \\
2 & $8.7 \%$ & 7 & $58.3 \%$ & 5 & $14.3 \%$ & 14 & $20.0 \%$ \\
0 & $0.0 \%$ & 0 & $0.0 \%$ & 3 & $8.6 \%$ & 3 & $4.3 \%$ \\
23 & & 12 & & 35 & & 70 &
\end{tabular}
a. same location and time
b. same location, different time
c. different location
d. not bought the things
e. other
Total 
Figure 3

Alternate Purchase (would have shopped...)

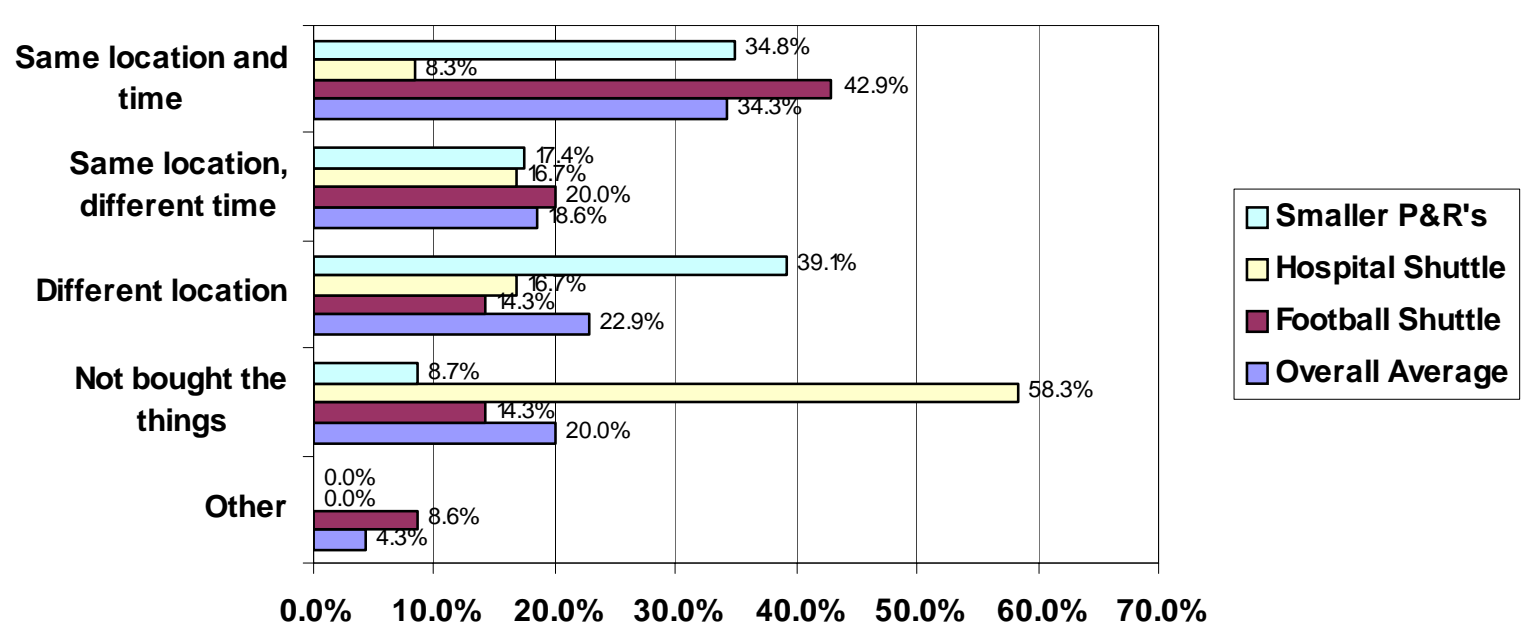

\section{Shopping Frequency}

The survey respondents were asked to list the number of times they shop at the shopping center in a typical week/football season when using the park and ride to get to their destination. Table 9 indicates the shopping frequency of the park and ride users. The overall average shopping frequency was 1.55 days per week for the smaller park and rides, 0.76 days per week for the hospital shuttle park and ride, and 1.72 game days per season for the football shuttle park and ride. Table 9 also displays the number range (days per week/season) that the responses fell under. The smaller group of smaller park and rides had significantly higher shopping frequencies than the hospital shuttle. In the smaller park and ride group, $42.6 \%$ of the 68 respondents indicated that they shop one to two days a week, and $20.6 \%$ indicated that they shop three to four days a week. In the hospital shuttle group, $35.7 \%$ of the 70 respondents indicated that they shop one to two days a week, and $8.6 \%$ indicated that they shop three to four days a week. The difference can most likely be attributed to the fact that, due to their nature, the smaller park and rides have a much higher frequency of use than the hospital shuttle. As discussed earlier, $89.7 \%$ of the 68 respondents from the smaller park and ride group use the park and ride daily, while only $22.9 \%$ of the 70 respondents from the hospital shuttle use the park and ride everyday. Of the football shuttle respondents, $21.0 \%$ of the 124 respondents shopped one to two game days a season, $12.9 \%$ shopped three to four game days a season, and $16.1 \%$ shopped five to six game days a season. 


\section{Table 9}

In a typical week, how many times do you shop at these stores when you park here for your trip to your destination?

\begin{tabular}{|c|c|c|c|c|c|c|}
\hline \multirow[b]{2}{*}{$\begin{array}{l}\text { Frequency of } \\
\text { Shopping }\end{array}$} & \multicolumn{2}{|c|}{ Smaller P\&R's } & \multicolumn{2}{|c|}{ Hospital Shuttle } & \multicolumn{2}{|c|}{ Total } \\
\hline & No. & Percent & No. & Percent & №. & $\underline{\text { Percent }}$ \\
\hline 5 days/week & 4 & $5.9 \%$ & 0 & $0.0 \%$ & 4 & $2.9 \%$ \\
\hline 3-4 days/week & 14 & $20.6 \%$ & 6 & $8.6 \%$ & 20 & $14.5 \%$ \\
\hline 1-2 days/week & 29 & $42.6 \%$ & 25 & $35.7 \%$ & 54 & $39.1 \%$ \\
\hline less than 1 & 21 & $30.9 \%$ & 39 & $55.7 \%$ & 60 & $43.5 \%$ \\
\hline Total & 68 & & 70 & & 138 & \\
\hline Average & 1.55 & & 0.76 & & 1.15 & \\
\hline
\end{tabular}

\section{Football Shuttle}

\begin{tabular}{|c|c|c|}
\hline Frequency of Shopping & No. & Percent \\
\hline a. 5-6 game days/season & 20 & $16.1 \%$ \\
\hline b. 3-4 game days/season & 16 & $12.9 \%$ \\
\hline c. 1-2 game days/season & 26 & $21.0 \%$ \\
\hline d. 0 game days/season & 62 & $50.0 \%$ \\
\hline Total & 124 & \\
\hline
\end{tabular}

Average $\quad 1.72$

The overall percentage of respondents who made purchases at the shopping center at least once a week when using the park and ride was $69.1 \%$ of 68 respondents for the smaller park and rides and $44.3 \%$ of 70 respondents for the hospital shuttle park and ride. Fifty percent of the 124 football shuttle respondents made purchases at the mall at least once a football season when using the park and ride.

\section{Average Weekly Purchases}

Table 10 and Figure 4 indicate the average amount spent on purchases in a typical week or game season. The average amount is calculated per shopper, as well as per park and ride user. The "shopper" refers to the average amount that a park and ride user actually spent. The "park and ride user" includes both park and ride users who shopped and those who did not shop in calculating the average amount spent. The smaller park and rides had a higher average weekly purchase amount (\$37.79 per shopper and \$26.12 per park and ride user) than the hospital shuttle park and ride (\$25.06 per shopper and \$12.17 per park and ride user), which can be expected since the smaller park and rides have a higher shopping frequency. The football shuttle park and ride had an average purchase amount of $\$ 72.09$ per shopper and \$37.21 per park and ride user in a typical season. 
Table 10

In a typical week, how much do you spend at these stores when you park here for your trip to your destination?

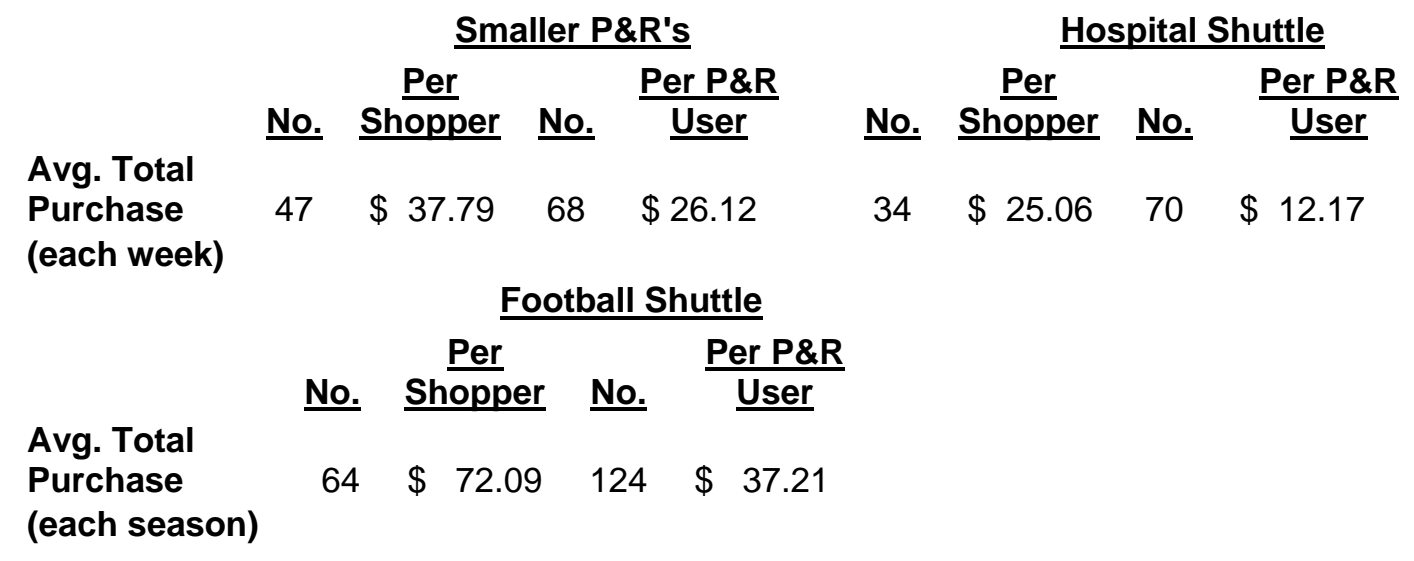

Figure 4

Average Total Purchases Each Weekl Game Season

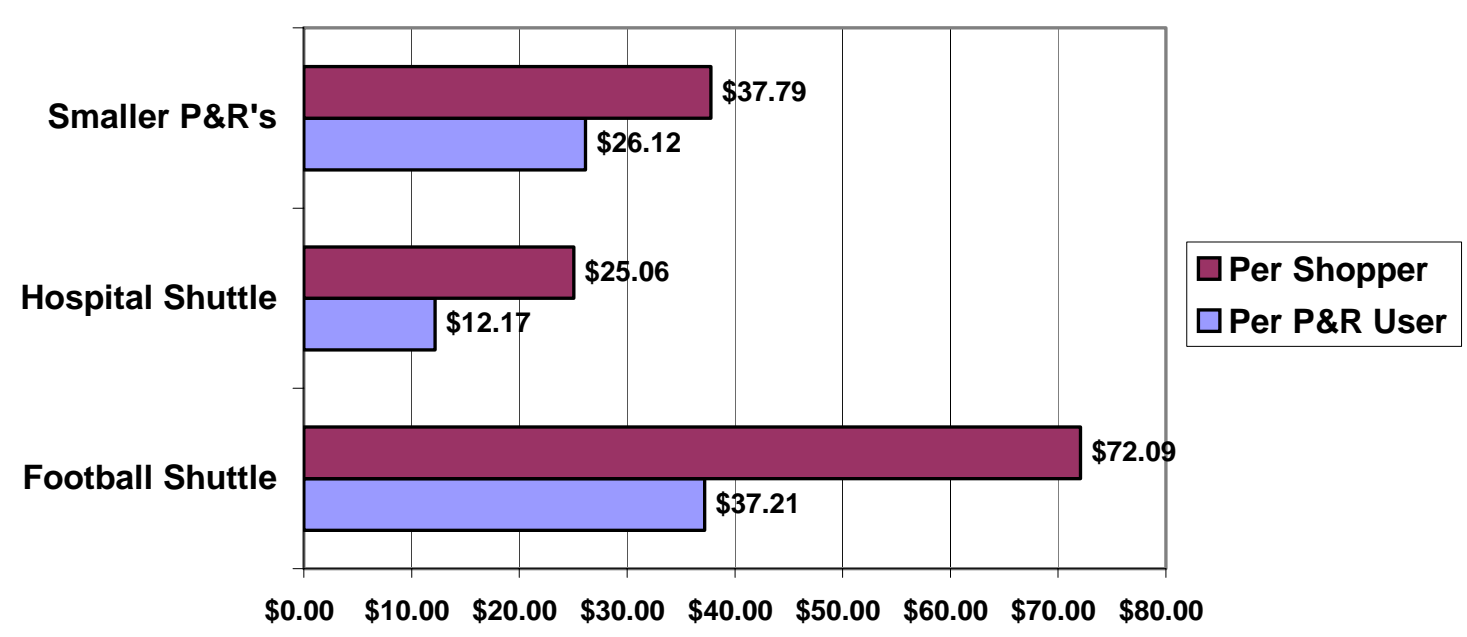

Alternative Analysis

Again, it is important to note that the actual averages for the amount spent are probably higher than the calculated averages because several of the respondents who indicated that they shopped at the shopping center each week/game season did not indicate how much they spent. The individual purchase amounts for those respondents were computed into the calculation as $\$ 0.00$. If those respondents who left the purchase amount blank are left out of the calculation, then the average purchase amount increases from \$25.06 to \$29.38 per shopper for the hospital shuttle park and ride and from $\$ 72.09$ to $\$ 90.47$ per shopper for the football shuttle park and ride. The average weekly purchase amount stays the same for the smaller park and rides. (See Table 11.) 


\section{Table 11}

In a typical week, how much do you spend at these stores

when you park here for your trip to your destination?

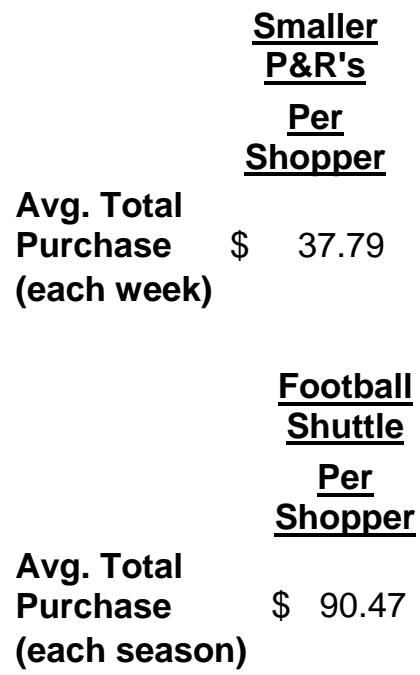

Alternatively, the average purchase amount can be calculated by replacing the $\$ 0.00$ 's of those shoppers who left the weekly purchase amount blank with the average purchase amounts from the first calculation. For example, for the smaller park and rides group the shoppers who left the weekly purchase amount blank would be counted as having spent $\$ 39.40$ (the smaller park and ride group's average from the first calculation) rather than $\$ 0.00$. When using this calculation, the average purchase amount per shopper is $\$ 39.40$ per week for the smaller park and rides, \$28.74 per week for the hospital shuttle park and ride, and \$77.67 per season for the football shuttle park and ride. (See Table 12.)

\section{Table 12}

In a typical week, how much do you spend at these stores when you park here for your trip to your destination?

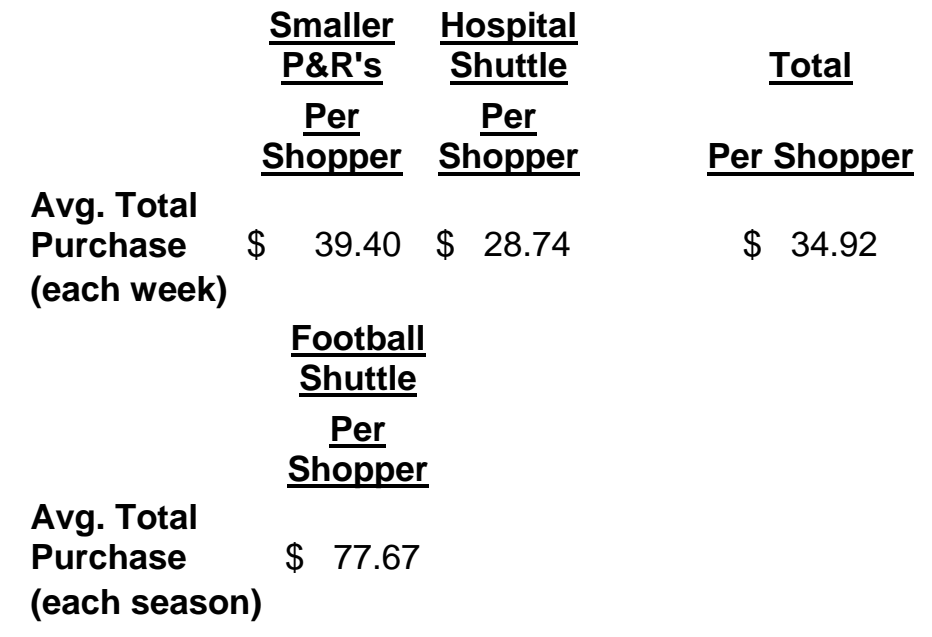




\section{Benefits to Users}

At the end of the survey, respondents were asked to rate how beneficial the availability of the park and ride has been to them on a scale of one to five-one being very beneficial and five being not beneficial. The purpose of this question was to gauge user satisfaction with the parking arrangements and possibly learn about any areas that could be improved. As detailed in Table 13 and Figure 5, the responses were overwhelmingly positive.

Overall, $83.5 \%$ of the 249 respondents gave a rating of one (very beneficial), $6.8 \%$ gave a rating of two, $6.8 \%$ gave a rating of three, $2.0 \%$ gave a rating of four, and $0.8 \%$ gave a rating of five (not beneficial). The football shuttle park and ride had the highest response rating, with $85.7 \%$ of the 112 respondents giving a rating of one, followed by the smaller park and rides, and then by the hospital shuttle.

\section{Table 13}

How beneficial has the availability of Park \& Ride been to you?

$$
\text { Smaller P\&R's Hospital Shuttle Football Shuttle }
$$

\begin{tabular}{|c|c|c|c|c|c|c|c|c|}
\hline How beneficial? & No. & Percent & No. & Percent & No. & Percent & No. & Percent \\
\hline a. 1 (very beneficial) & $\overline{57}$ & $83.8 \%$ & 55 & $79.7 \%$ & 96 & $85.7 \%$ & 208 & $83.5 \%$ \\
\hline b. 2 & 4 & $5.9 \%$ & 5 & $7.2 \%$ & 8 & $7.1 \%$ & 17 & $6.8 \%$ \\
\hline c. 3 (beneficial) & 5 & $7.4 \%$ & 6 & $8.7 \%$ & 6 & $5.4 \%$ & 17 & $6.8 \%$ \\
\hline d. 4 & 1 & $1.5 \%$ & 2 & $2.9 \%$ & 2 & $1.8 \%$ & 5 & $2.0 \%$ \\
\hline e. 5 (not beneficial) & 1 & $1.5 \%$ & 1 & $1.4 \%$ & 0 & $0.0 \%$ & 2 & $0.8 \%$ \\
\hline Total & 68 & & 69 & & 112 & & 249 & \\
\hline
\end{tabular}


Figure 5

How Beneficial Has the Park and Ride Been?

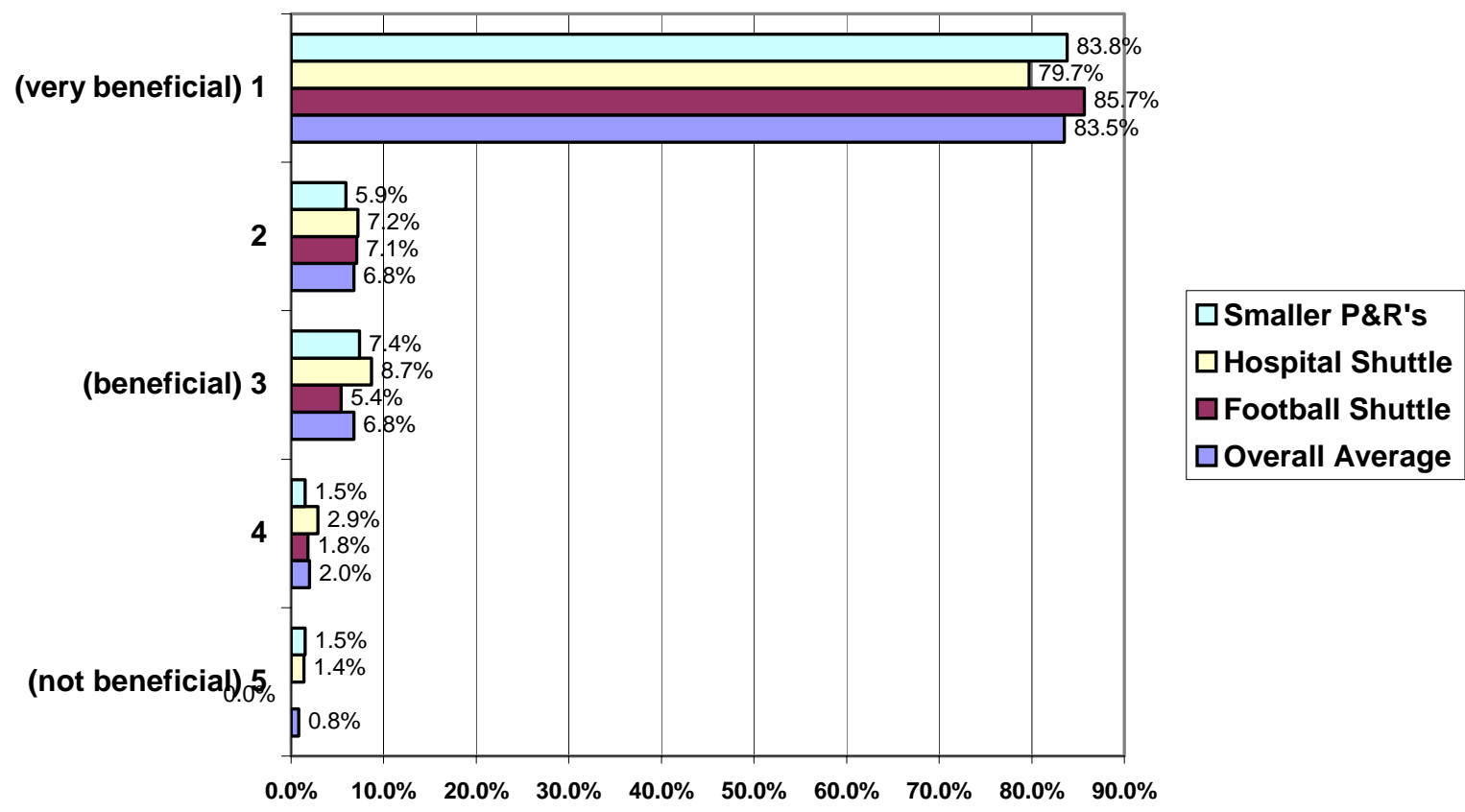

\section{Comparative Summary With Previous Studies}

The table below shows some of the common elements between the findings from this study and the previous studies in Maryland and California discussed in literature review. While different from one another, they all show evidence of use of shared park and ride, of mode shift (resulting from use of park and ride), diverted shopping, and expenditures made at these and nearby retail facilities.

Table 14

\begin{tabular}{|l|l|l|l|l|l|l|l|}
\hline \multirow{2}{*}{ Location/Activity } & \multicolumn{3}{|l|}{ Florida Study 2003 } & $\begin{array}{l}\text { MD } \\
\mathbf{1 9 8 2}\end{array}$ & $\begin{array}{l}\text { CA } \\
\mathbf{n y y y y y n}\end{array}$ & Games \\
\hline $\begin{array}{l}\text { Parked } 5 \text { times per } \\
\text { week }\end{array}$ & $62 \%$ & $22 \%$ & $90 \%$ & $55 \%$ & $65 \%$ & $\begin{array}{l}\text { Hospital } \\
\text { P\&Rs }\end{array}$ \\
\hline $\begin{array}{l}\text { \% Shopped } \\
\text { (unweighted) }\end{array}$ & $40 \%$ & $38 \%$ & $39 \%$ & $38 \%$ & $\begin{array}{l}24- \\
40 \%\end{array}$ & $4 /$ month \\
\hline $\begin{array}{l}\text { \% Diverted } \\
\text { Shopping }\end{array}$ & $14 \%$ & $16 \%$ & $39 \%$ & $23 \%$ & $67 \%$ & $12 \%$ & \\
\hline $\begin{array}{l}\% \text { Induced } \\
\text { Shopping }\end{array}$ & $14 \%$ & $58 \%$ & $9 \%$ & $20 \%$ & $\$ 18.55$ & $\$ 46.79$ \\
\hline & Recent Expenditure & $\$ 25$ & $\$ 14$ & $\$ 21$ & $\$ 22$ & & \\
\hline
\end{tabular}




\section{CONCLUDING OBSERVATIONS}

The purpose of this research was to document the economic benefit of shared use park and ride facilities located at retail centers. The research attempted to answer three main research questions. First, does the presence of a "Shared Use Park \& Ride" have influence on shopping behavior patterns of users? Secondly, does the presence of a "Shared Use Park \& Ride" generate revenues for shared use park and ride providers? And finally, does the presence of a "Shared Use Park \& Ride" generate ridership for transit service providers? Further comparative review with other previous studies similarly reveals the potential for increase in customer base as well as sales revenues.

The research indicates that the park and ride users at the survey sites are indeed shopping at the shopping centers when they park at the park and ride. As discussed earlier, 69.1\% of the 68 respondents from the smaller park and rides shopped at the shopping center at least once a week when using the park and ride, spending a weekly average of $\$ 37.79$ per shopper. Forty four percent of the 70 respondents from the hospital shuttle park and ride shopped at the shopping center at least once week when using the park and ride, spending a weekly average of $\$ 25.06$ per shopper. Fifty percent of the 124 respondents from the football shuttle park and ride shopped at least once a football season when using the park and ride, spending an average of $\$ 72.09$ per shopper each football season. Looking at the bigger picture, these weekly averages could translate into annual expenditures of $\$ 1,965.08$ per shopper for the smaller park and rides and \$1,303.12 per shopper for the hospital shuttle park and ride. Furthermore, a significant proportion of those users would not have shopped at the retail center if the park and ride lot did not exist. Overall, $42.9 \%$ of the 70 shoppers would have either made their purchases elsewhere or not have made the purchases at all if they had not used the park and ride at that shopping center. These results show that the shared use park and rides studied actually did increase the shopping centers' customer base.

While a direct comparison is not possible without consideration of local conditions, available transit services, the type of arrangements and the periods of the study, these findings mirror the Smith study in a number of ways. These include parking 5 times a week (55\% versus $65 \%$ ), percent of users who shopped (38\% versus $40 \%$ ), and amount of recent expenditures ( $\$ 22$ versus $\$ 18.55$ ) between this study and Smith’s study respectively. Noticeable differences included diverted shoppers (23\% versus $67 \%$ ) and induced shoppers (20\% versus $12 \%$ ) between this study and Smith's study respectively.

Several factors can affect the comparison even within a specific study. As seen in this study, there are several factors that can affect the shopping frequency of shared use park and ride users. The type of park and ride service provided (e.g., operated daily or used only for special events) can determine how often people can use the park and ride, which in turn affects shopping frequency. The demographics of the park and ride users themselves also affects how often they will shop. As seen in the case of the hospital shuttle, many of the park and ride users were patients of the hospital and only used the park and ride occasionally to get to medical appointments. The hospital shuttle's average shopping frequency was much lower than that of the more traditional park and rides, in 
which the users were employees commuting to work everyday. Although not examined in this research, a number of other factors can play a role in how much park and ride patrons use the adjacent shopping facilities, such as the mix of retail shops available at the shopping center where shared use park and ride is located, the distance between park and ride spaces and business entrances, and the condition of the pathways from the park and ride to the shopping area.

Another major finding was that the presence of park and ride lots did have an impact on modal choice. Almost half of all of the survey respondents reported that they would have driven their cars all the way to their destination if the park and ride lot had not been there. This significant modal shift from automobile trips to using transit indicates that the presence of a shared use park and ride does generate ridership for transit service providers.

Implications of these research findings indicate that shopping centers might benefit if they are willing to allow their properties to be used for shared use park and ride. It also shows that transit agencies may be able to provide concrete research data to prove to prospective shared use park and ride providers that they will benefit financially through an increased customer base and new revenues.

Other implicit impacts include relief on local traffic congestion and decrease on demand for parking at destination sites. Consequently, there is potential for secondary effects on vehicle miles traveled, environmental impacts and other transportation related costs such as road maintenance, accidents, etc.

\section{Recommendations:}

It is recommended that similar research be expanded upon and conducted on a larger scale with direct transit agency involvement. This would help identify parameters for an ideal park and ride location, operational considerations and an account of all types of shared use park and ride facilities. While participation of park and ride providers would enhance the process further, full participation by transit agencies would allow surveys to be done at bus stops where park and ride providers are reluctant to allow surveyors on their property. Additionally, an analysis of property owners hesitant to participate in shared park and ride facilities might provide a better understanding of partnership issues and benefits. Further research in other states or at a national level will provide a better comparative picture.

Future research should also explore the shopping centers' point of view, in terms of how much profit they hope to make from this type of arrangement in order to make it worthwhile for them (e.g., a spending ratio that includes the number of shared parking spaces being utilized as well as the number of hours the spaces are in use each week). It is important to consider what level of spending per park and ride user is meaningful to prospective park and ride providers. Another issue to look into is whether the shared parking spaces would stay vacant if there was no shared park and ride. If the shared use park and ride would actually take up spaces needed by customers, then factors such as 
how often those customers come to the shopping center and how much they spend (in comparison to how much the park and ride users would spend) should also be considered when determining if a shared use park and ride arrangement would be economically beneficial to the shopping center. 


\section{APPENDICES}

\section{Appendix 1}

1) Your primary purpose for using this Park \& Ride is to: Check all that Apply

Walk to my destination

Bike to my destination

Carpool to my destination

Vanpool to my destination

Ride transit to my destination

Other

2) How often do you park here?
a) Usually 5 days a week
b) 3-4 days a week
c) 1-2 days a week
d) Less than that

3) Did you park here yesterday?
a) Yes
b) No
(If no, skip to question 7)

4) If the lot had not been here, what would you have done to get to your destination yesterday?
a) Would have parked nearby (within walking distance) and caught the same bus or car- pool
b) Would have caught the bus or met the car-pool somewhere else
c) Would have driven all the way to my destination
d) Other

5) Did you shop at any of the stores here yesterday on your way to or from your destination?
a) Yes
b) No
(If no, skip to question 7)
c) If yes, about how much did you spend?
$\$$

6) If this lot had not been here, what would you have done about obtaining yesterday's purchases?

a) Bought the same things at this location on the way to or from my destination

b) Bought the same things at this location at a different time (list probable day and time as best you can)

c) Bought the same things at a different location (list probable day and time as best you can)

d) Not bought the things

e) Other

7) In a typical week, how many times do you shop at these stores when you park here for your trip to your destination?

8) In a typical week, how much do you spend at these stores when you park here for your trip to your destination? \$

9) How beneficial has the availability of Park \& Ride been to you? (Please rank).

$\underline{\text { Very beneficial } \leftrightarrow \text { Beneficial } \leftrightarrow \text { Not beneficial }}$

$1 \quad 2 \quad 3 \quad 4 \quad 5$




\section{Appendix 2}

The modified survey questions are listed below:

1) Your primary purpose for using this Park \& Ride is to: Check all that Apply

Walk to my destination

Bike to my destination

Carpool to my destination

Vanpool to my destination

Ride transit (shuttle) to my destination

Other

2) How often do you park here?
a) More than $75 \%$ of the game days
b) $50-75 \%$ of the game days
c) $25-50 \%$ of the game days
d) Less than 25 percent of the game days

3) Did you park here for the most recent game?
a) Yes
b) No
(If no, skip to question 7)

4) If the lot had not been here, what would you have done to get to your destination on that day?

a) Would have parked nearby (within walking distance) and caught the same bus or carpool

b) Would have caught the bus or met the car-pool somewhere else

c) Would have driven all the way to my destination

d) Other

5) Did you shop at any of the stores here on that day on your way to or from your destination?
a) Yes
b) No
(If no, skip to question 7)
c) If yes, about how much did you spend?
$\$$

6) If this lot had not been here, what would you have done about obtaining that day's purchases?

a) Bought the same things at this location on the way to or from my destination

b) Bought the same things at this location at a different time (list probable day and time as best you can)

c) Bought the same things at a different location (list probable day and time as best you can)

d) Not bought the things

e) Other

7) In a typical game season, how many times do you shop at these stores when you park here for your trip to your destination?

8) In a typical game season, how much do you spend at these stores when you park here for your trip to your destination? \$

9) How beneficial has the availability of Park \& Ride been to you? (Please rank). $\underline{\text { Very beneficial }} \leftrightarrow$ Beneficial $\leftrightarrow$ Not beneficial

$\begin{array}{lllll}1 & 2 & 3 & 4 & 5\end{array}$




\section{ENDNOTES}

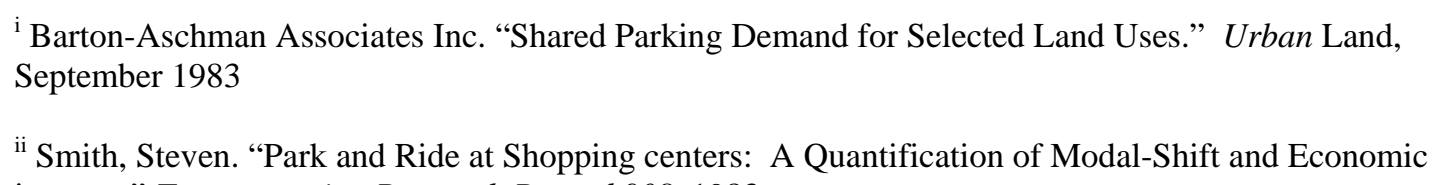
impacts.” Transportation Research Record 908, 1983.

iii American Association of State Highway and Transportation Officials. Guide for the Design of Park-andRide Facilities. Washington, D.C., 1992.

iv Public Technology, Inc. “The Coordination of Parking With Public Transportation and Ridesharing." U.S. Department of Transportation, Washington, D.C., 1982.

${ }^{v}$ Smith, Steven. "Park and Ride at Shopping centers: A Quantification of Modal-Shift and Economic impacts.” Transportation Research Record 908, 1983.

${ }^{v i}$ Wambalaba, F., Gabourel, K., and Goodwill, J., Commuter Choice Managers and Parking Managers Coordination, National Center for Transit Research (NCTR) project, Contract No. BC 137, RPWO \#38, Public Transportation Synthesis Series, Fall 2002.

vii Trout, N.D. and Ulman, G.L. Special Event Park-and-Ride Shuttle Bus Success Story. ITE Journal: 3843, 1997.

${ }^{\text {viii }}$ Frederic R. Harris, Inc. State Park \& Ride Lot Program. Florida Department of Transportation, 1989.

${ }^{\text {ix }}$ Foote, P.J. Chicago Transit Authority Weekday Park-and Ride Users: Choice Market with Ridership Growth Potential. Transportation Research Record: No. 1735, 158-168, 2000.

x Allen, W.G., Modeling Carpool and Transit Park-And-Ride Lots. Sixth TRB Conference on the Application of Transportation Planning Methods, 1997.

xi Spillar, R. Smart Parks: The Next Generation in Park-and Ride-Facilities. National Parking Association: 30-31, 1999.

xii Turnbull, K. Effective Use of Park-and Ride Facilities. NCHRP Synthesis, 1995.

xiii Shopping Centers Make a Profit on Park-and-Ride, Newsletter, Office of Highway Planning, FHWA, Issue No. 5, Sept. 1978.

xiv Southern California Rapid Transit District. “Shopping Center Park and Ride Users' Survey: Line 716, 760, 762.” Los Angeles, California, July 1982.

${ }^{x v}$ Dansker, B. and M. Laube, Park-and-Ride at Shopping Centers: A Quantification of Modal-Shift and Economic Impacts. Transportation Research Record: No. 908, 1983, 27-31.

xvi Smith, Wilbur. "What's New in Parking.” Planning, 1983.

${ }^{\text {xvii }}$ Hinebaugh, D., Land, L. and Staes, L. Public Transit Access to Private Property. Center for Urban Transportation Research, 2000. 
xviii Barton-Aschman Associates Inc. “Shared Parking Demand for Selected Land Uses.” Urban Land, September 1983

${ }^{\text {xix }}$ Federal Highway Administration. Parking Management Tactics Volume III: A Reference Guide. Washington D.C:. Federal Highway Administration, 1981.

${ }^{x x}$ Public Technology Inc. ”The Coordination of Parking with Public Transportation and Ridesharing.” Urban Consortium Information Bulletin, June 1982.

${ }^{x x i}$ Federal Highway Administration. Parking Management Tactics Volume III: A Reference Guide. Washington D.C:. Federal Highway Administration, 1981.

xxii Public Technology Inc. ”The Coordination of Parking with Public Transportation and Ridesharing.” Urban Consortium Information Bulletin, June 1982.

xxiii Federal Highway Administration. Parking Management Tactics Volume III: A Reference Guide. Washington D.C:. Federal Highway Administration, 1981.

${ }^{\text {xxiv }}$ Barton-Aschman Associates Inc. "Shared Parking Demand for Selected Land Uses.” Urban Land, September 1983.

${ }^{x x v}$ Hinebaugh, D., Land, L. and Staes, L. Public Transit Access to Private Property. Center for Urban Transportation Research, 2000.

${ }^{x x v i}$ Frederick R. Harris, Inc. State Park \& Ride Lot Program Planning Manual. Florida Department of Transportation, 1989.

xxvii Tri-Met internal policy document

xxviii Robin Anderson, Transit Planner, King County Department of Transportation, email correspondence, 6/17/03.

${ }^{\text {xxix }}$ Barbara Ladner, Pace Suburban Bus Service, email correspondence, 6/10/03.

${ }^{x x x}$ Wambalaba, F., Gabourel, K., and Goodwill, J., Commuter Choice Managers and Parking Managers Coordination, National Center for Transit Research (NCTR) project, Contract No. BC 137, RPWO \#38, Public Transportation Synthesis Series, Fall 2002.

xxxi Southern California Rapid Transit District. "Shopping Center Park and Ride Users' Survey: Line 716, 760, 762.” Los Angeles, California, July 1982.

xxxii Smith, Steven. "Park and Ride at Shopping centers: A Quantification of Modal-Shift and Economic impacts.” Transportation Research Record 908, 1983.

xxxiii ICF Kaiser Engineers and Moore/Bowers. Regional Park and Ride Lot Plan. Florida Department of Transportation District Seven, 1994.

${ }^{\text {xxxiv }}$ Wambalaba, F., Gabourel, K., and Goodwill, J., Commuter Choice Managers and Parking Managers Coordination, National Center for Transit Research (NCTR) project, Contract No. BC 137, RPWO \#38, Public Transportation Synthesis Series, Fall 2002. 